\section{Kastamonu Eğitim Dergisi Kastamonu Education Journal}

Mayıs 2019 Cilt:27 Sayı:3

kefdergi.kastamonu.edu.tr
Başvuru Tarihi/Received: 13.02.2018

Kabul Tarihi/Accepted: 18.07.2018

DOI: $10.24106 /$ kefdergi.2685

\title{
Öğretmenlerde Örgütsel Bağlılığın Çeşitli Değişkenler Açısından İncelenmesi: Bir Meta-Analiz Çalışması
}

\section{Investigating the Organizational Commitment of Teachers According to Some Variables: A Meta-Analysis Study}

\section{Öz}

\author{
Songül TÜMKAYA ${ }^{1}$, Hakan ULUM ${ }^{2}$
}

Bu araştırmada cinsiyet, medeni durum ve branş değişkenlerinin, öğretmenlerin örgütsel bağ|ılığı üzerindeki etkisinin meta-analiz yöntemiyle birleştirilmesi amaçlanmıştır. Çalışmalardan hangilerinin meta analize dâhil edileceğine ilişkin belirli ölçütler kullanılmıştır. Bu ölçütler şunlardır: 2009-2017 yılları arasında yapılan çalışmalar olması; cinsiyet, medeni durum, branş değişkenlerinin en az birisi üzerinde istatistiksel bulgu elde edilen tarama çalışmalar olması, Allen ve Meyer (1990)' in örgütsel bağlılık sınıflandırmasını (duygusal bağlılık, devam bağlıı̆̆ı ve normatif bağlılık) dikkate alan çalışmalar olması, örneklem grubunun öğretmenlerden oluşması ve Türkiye'de yapılan çalışmalar olmasıdır. Bu araştırmada 23 çalışma meta analize dahil edilmiştir. Bütün araştırmalarda aynı değişkenler ele alınmadığı için cinsiyet, medeni durum ve branş değişkenleri için meta analize dâhil eden çalışma sayısı farklıdır. Genel etkinin hesaplanması için öncelikle yayın yanlılığı istatistiğine bakılmış, heterojenlik testi yapılmış, uzman görüşüne başvurulmuş ve sonuçlarına göre sabit etki modeli veya rastgele etkiler modeline göre analiz sonuçları değerlendirilmiştir. Etkisi araştırılan değişkenlerden cinsiyet [duygusal bağlılık alt boyutu için (ED=-0.114), devam bağııı̆̆ alt boyutu için (ED=-0.072), normatif bağlılık alt boyutu için (ED=-0.153)], medeni durum [duygusal bağlılık alt boyutu için (ED=-0.111), devam bağ|ılığı alt boyutu için (ED=-0.069), normatif bağ|ılık alt boyutu için (ED=-0.109) ],branş [duygusal bağılık alt boyutu için (ED=-0.197), devam bağlılığı alt boyutu için (ED=-0.073), normatif bağlılık alt boyutu için ( $E D=-0.202)$ ], öğretmenlerin örgütsel bağlılıkları üzerinde önemsiz düzeyde etkilidir. Araştırmada cinsiyetin örgütsel bağlıı̆ın duygusal bağlılık, devam bağıı̆ı̆ı ve normatif bağlılık boyutlarında erkek öğretmenlerin kadın öğretmenlere göre daha fazla duygusal bağ|ılık yaşadığı sonucuna, medeni durum değişkeninde örgütsel bağlılığın duygusal bağlılık, devam bağlılığı ve normatif bağlılık boyutlarında bekar öğretmenlerin evli öğretmenlere göre daha fazla duygusal bağlılık yaşadığı sonucuna ve branş değişkeninde örgütsel bağlılığın duygusal bağ|ılık, devam bağ|ılığı ve normatif bağlılık boyutlarında sınıf öğretmenlerinin branş öğretmenlerine göre daha fazla duygusal bağlılık sergilediği sonucuna ulaşılmıştır..

Anahtar Kelimeler: meta-analiz, öğretmen, örgütsel bağlılık.

\section{Abstract}

Within this study, by means of a meta-analysis inquiry, it was aimed to synthesize the effects of gender, marital status and branch variables on teachers' organizational commitment. Specific criteria were used to comprehend which studies would be included in the meta-analysis. These criteria refer to the studies conducted between 2017-2018, the field scanning studies with statistical data on gender, marital status, and branch variables, the studies on the classification of institu-tional commitment (emotional commitment, participation commitment, and normative commitment) by Allen and Meyer (1990), the studies the samples of which cover teachers, and the studies conducted in Turkey. In this study 23 studies have been included in the meta-analysis. With the aim of counting the general effects, the following steps were taken: statistics of publication bias was initially taken into consideration; a heterogeneity test was conducted; experts' views were noted and the analysis results were evaluated through stable effect model and random effect model. Gender, one of the variables the effect of which is inquired, was found out to bear small significance on the institutional commitment of teachers sub-dimension emotional commitment $(E D=-0.114)$, sub-dimension participation commitment $(E D=-0.072)$, sub-dimension normative commitment $(E D=-0.153)$, marital status emotional commitment sub-dimension ( $E D=-0.111$ ), participation sub-dimension (ED=-0.069), normative commitment sub-dimension ( $E D=-0.109)$, branch emotional commitment sub-dimension $(E D=-0.197)$, participation sub-dimension $(E D=-0.073)$, normative commitment sub-dimension ( $E D=-0.202)$. The results of the study suggest that compared to male teachers, female teachers feel more emotional commitment with respect to the sub-dimensions of institutional commitment-emotional, participation, and normative commitments regarding the gender, compared to single teachers, married teachers bear more emotional commitment with respect to the sub-dimensions of institutional commitment-emotional, participation, and normative commitments regarding marital status, and compared to field teachers, class teachers represent more emotional commitment with respect to the sub-dimensions of institutional commitment-emotional, participation, and normative commitments regarding the branch variable.

Keywords: meta-analysis, teacher, organizational commitment.

1. Çukurova Üniversitesi, Eğitim Fakültesi,Adana, Türkiye.; https://orcid.org/0000-0003-0140-4640

2. Çukurova Üniversitesi, Sosyal Bilimler Enstitüsü,Adana, Türkiye.;. https://orcid.org/0000-0002-1398-6935

Atıf / Citation: Tümkaya, S., \& Ulum, H. (2019). Öğretmenlerde örgütsel bağlılığın çeşitli değişkenler açısından incelenmesi: Bir meta-analiz çalışması. Kastamonu Education Journal, 27(3), 1103-1121. doi:10.24106/kefdergi.2685 


\section{Extended Summary}

Introduction : In this study, it was aimed to determine the effects of gender, marital status and branch variables on teachers' organizational commitment. For this purpose, a meta-analysis inquiry has been carried out with respect to the organizational commitment of teachers in Turkey. Within this context, similar studies were grouped within certain criteria and quantitative findings belonging to these studies were combined and interpreted.

Method: A rigorous literature search for the meta-analysis inquiry was performed. With this aim, 198 thesis and 48 articles were examined. The study was passed through some filters utilizing specified criteria. 28 studies ( 25 theses, 3 articles) were perused. However, since the same variables were not used in all studies, the number of studies including the meta-analysis inquiry for gender, marital status, and branch variables represented variation. The obtained data were analyzed using the Comprehensive Meta-Analysis (CMA) package program.

Conclusion and Discussion: Regarding the gender variable, through the mean effect size of 19 studies utilized in our study, the emotional commitment was calculated. The $95 \%$ the confidence interval was found out to be $-0,186$ and the mean effect size at the upper limit was seen as $-0,042 \mathrm{ES}=-0,114$. According to gender variable, male teachers were seen to represent more emotional commitment than female teachers within the sub-dimension emotional commitment of organizational commitment dimension. It was determined that the effect size value had a small effect. For the gender variable, by looking at the mean effect size of 18 studies included we counted the participation commitment. The $95 \%$ confidence interval was found out to be $-0,118$, besides the mean effect size at the upper limit of $-0,026$ ES $=-0,072$. According to gender variable, male teachers had more participation commitment than female teachers by looking at the sub-dimension of participation commitment of organizational commitment dimension. It was seen that the effect size value had a small significance. Furthermore, for the gender variable, the mean effect size of 18 studies included in the study was used to calculate the normative commitment as well. The $95 \%$ confidence interval was found out to be $-0,24$, besides the mean effect size at the upper limit of $-0,049 \mathrm{ES}=-0,153$. By looking at the gender variable, male teachers had more normative commitment than female teachers in the sub-dimension of normative commitment of organizational commitment. It has been determined that the effect size value had a small significance.

With the aim of inquiring the relation of marital status variable with emotional commitment sub-dimension, through the mean effect size of 17 studies included in the study, the emotional commitment was calculated. The $95 \%$ confidence interval was found to be $-0,169$, besides the mean effect size at the upper limit of $-0,054 E S=-0,111$. Looking at the marital status, married teachers were seen to have more emotional commitment compared to single teachers with respect to the sub-dimension emotional commitment of the organizational commitment dimension. It was understood that the effect size value had a small significance. For the marital status variable, through the mean effect size of 16 studies included in the study, participation commitment was calculated and the $95 \%$ confidence interval was found out to be $-0,12$, besides the mean effect size at the upper limit of $-0,010 \mathrm{ES}=-0,069$. Having a look at the marital status, married teachers were seen to have more participation commitment compared to single teachers in terms of the sub-dimension of participation commitment of organizational commitment dimension. It was understood that the effect size value had small significance. As for the marital status variable, through the mean effect size of 17 studies included in the study, normative commitment was also calculated. The $95 \%$ confidence interval was found out to be $-0,167$, besides the mean effect size at the upper limit of $-0,052 \mathrm{ES}=-0,109$. So, by looking at the marital status variable, married teachers were found out to have more normative commitment compared to the single teachers in the sub-dimension of normative commitment of organizational commitment dimension. It was seen that the effect size value had a small significance.

In terms of the branch variable, by means of the mean effect size of 7 studies included within our study, the emotional commitment was calculated. The $95 \%$ confidence interval was found out to be $-0,333$, besides the mean effect size at the upper limit of $-0,061 \mathrm{ES}=-0,107$. Regarding the branch sub-dimension, class teachers had been found out to bear more emotional commitment compared to branch teachers. It was comprehended that the effect size value had a small significance. Similarly, for the branch variable, through the mean effect size of 7 studies included in the study, participation commitment sub-dimension was calculated and the $95 \%$ confidence interval was found out to be $-0,151$, besides the mean effect size at the upper limit of $-0,004 \mathrm{ES}=-0,073$. Considering the branch variable, class teachers were found out to have more participation commitment compared to the branch teachers in the sub-dimension participation commitment of organizational commitment. It was realized that the effect size value has a small significance. Moreover, regarding the branch variable, over the mean effect size of 7 studies included in the study, the normative commitment sub-dimension was calculated and the $95 \%$ confidence interval was found out to be $-0,352$, besides the mean effect size at the upper limit of $-0,053 \mathrm{ES}=-0,202$. By looking at the branch variable, class teachers were observed to have more normative commitment compared to the branch teachers in the sub-dimension of normative commitment of organizational commitment. It was acquired that the effect size value had a small significance.

| Kastamonu Eğitim Dergisi, 27(3), 2019| 


\section{Giriş}

Eğitim örgütlerinin amacına ulaşmasında önemli bir etken de öğretmenlerdir. Öğretmenlerin bağlı oldukları kuruma bağlııklarının türü ve derecesi örgütlerin amaçlarının gerçekleşmesi açısından dikkat edilmesi gereken bir noktadır. Bu konuda çeşitli yöntemlerle yapılacak araştırmalar eğitimin amacına ulaşması bakımından katkı sağlayacaktır.

Nicel araştırma yöntemleri hem Fen Bilimleri alanında hem Sosyal Bilimlerde yaygın biçimde kullanılan araştırma yöntemleri olmuştur. Eğitim alanındaki araştırmalarda da geleneksel olarak positivist anlayış hâkim olmuş ve nicel araştırma yöntemleri bu alanda da sıklıkla kullanılmıştır. Nicel araştırmaların ortaya koyduğu genellenebilir bilgiler öğretmen yetiştirme, program geliştirme gibi eğitimin çeşitli alanlarında kullanılmıştı (Acar, 2015). Ancak tek bir araştırmanın yeterince kesin sonuçlar ortaya koymasına sık rastlanmaz. Bu bakımdan, belli bir konu ile ilgili benzer araştırma sorularını açıklayan araştırmaların sentezi önemlidir (Yılmaz, Altınkurt ve Yıldırım, 2015). Bu bağlamda birbirinden ayrı olarak yapılan çalışmalardan elde edilen bulguları birleştiren meta-analiz çalışmaları önemlidir. Rosenthal ve DiMatteo (2001) bir meta-analiz çalışmasının, herhangi bir birincil çalışma veya anlat derlemesinden çok daha doğru, güvenilir ve genellenebilir sonuçlar sağlayacağını belirtmişlerdir. Chalmers ve arkadaşları (2002) meta-analizlerin karar verme sürecindeki önemi üzerinde durmuşlar ve meta analizlerin gelecekteki pozisyonunun büyük ihtimalle, birincil çalışmalar tarafindan sağlanan bilgi kırıntılarının araştırma sonuçlarına dayalı karar almak isteyen insanlara yeterli yararı sağlamayacağını belirtmişlerdir. Bu bakımdan bir alanda ve bir konu üzerinde yapılmış olan nicel araşttrmaların bulgularının tümünün birleştirilmesine dayanan meta-analiz çalışmaları, o alana bir üst bakış açısı getirmekte, yeni model ve kuramlar oluşturulmasına katkı sağlamaktadır (Erkuş, 2009).

Meta-analizin en güçlü yönlerinden birisi, geleneksel anlat derlemelerinde ortaya çıkan subjektif kararlar ve temsil gücü zayıf örneklemler gibi sınırlılıklara karşı dirençli olmasıdır. Ayrıca meta-analizlerde birincil çalışmaların örneklem sayısının birleştirilmesi hem istatistiksel gücün ve hassasiyetin artmasını sağlamakta hem de sonuçlarda oluşabilecek tutarsızlıkların sebeplerini araştırma olanağı sağlamaktadır. İnsanın çok büyük miktarda veriyi aynı anda güvenilir ve geçerli şekilde işleme kabiliyetinin olmaması nedeniyle meta-analiz çalışmaları kullanışlı olmaktadır (Borenstein vd., 2009; Glass, 2006; Hunter ve Schmidt, 2004; Petticrew, 2003; Petticrew ve Roberts, 2006). Bu güçlü yöne rağmen Türkiye'de az sayıda meta-analiz çalışması yapılmıştr. Anahtar sözcük olarak "meta analiz" yazıldığında Ulusual Tez Merkezinde, 129meta-analiz tezi listelenmektedir. Bu tezlerden 55 tanesi eğitim-öğretim konusundadır. 2016-2017 yıllarında meta-analiz çalışmalarında önemli bir artı̧̧ olduğu gözlenmiştir. Yine Ulusal Akademik Ağ ve Bilgi Merkezinde yapılan taramada ise 82 meta-analiz çalışmasına listelenmiştir. Örgütsel bağlılık konusunda (Aydın, Sarıer ve Uysal, 2011; Ülbeği ve Yalçın, 2016; Gedik ve Üstüner, 2017; Tak, Acar Erdur ve Kitapçı, 2011)meta-analiz çalışmaları son yıllarda karşımıza çıkmaktadır. Ancak öğretmenlerin örgütsel bağııığını çeşitli değişkenler (cinsiyet, branş ve medeni durum) açısından birlikte inceleyen bir meta-analiz çalışmasına rastlanmamıştır.

Alan yazın incelendiğinde örgütsel bağlılığın farklı tanımları karşımıza çıkar. Yaygın olarak örgütsel bağıılık "bir bireyin kimliğinin belli bir organizasyonda yer alması ve buna dâhil olmasının göreceli gücü" olarak tanımlanır (Mowday, Porter, ve Steers, 2008). Meyer ve Allen (1990) tarafindan, bir çalışanın örgütle ilişkisi ile ilişkilendirilen ve örgüt üyeliğine devam edip etmeyeceği ya da çalışmaya devam edip etmeyeceği konusunda, çalışanın kararında etkili olan duygusal bir bağ olarak tanımlanmıştır. O’Reilly ve Chatman (1986) örgütsel bağlılığı, insanın ilişkili olduğu örgüt ile olan psikolojik bağ şeklinde tanımlamıştır. Caught ve Shadur 2000) ise, çalışanların kurumun hedeflerine ulaşmada yardımcı olmayı taahhüt etme durumu ve çalışanların tanımlama, katılım ve sadakat düzeyleri olarak tanımlar.

Türkiye'de yapılan araşttrmalarda (Akgül, 2014; Aslan, 2017; Aydoğan, 2010; Başyiğit, 2009; Coşkun, 2012; Gören, 2012; Karaköse, 2012; Kılıçoğlu, 2010: Korkmaz, 2014, Kurşunoğlu vd., 2010; Menep; 2009; Özkan, 2010; Serdaroğlu, 2013; Yörük ve Sağban, 2012; Sönmez, 2016; Uştu, 2014; Uysal, 2014; Vurdu, 2017; Yalçın, 2009) sıklıkla Allen ve Meyer 'in (1990) örgütsel bağlılık sınıflandırmalarının kullanıldığı gözlenmektedir. Bu sınıflandırmada örgütsel bağııık, üç boyutta ele alınmaktadır. Bunlar; duygusal bağlılık, devam bağlılığı ve normatif bağlııktır. Allen ve Meyer 'a (1990) göre:

Duygusal bağlılık, bireylerin örgütün amaçlarını ve değerlerini tam olarak benimsediğinde ortaya çıkar. Organizasyonla duygusal olarak ilgilenirler ve organizasyonun başarı düzeyinden kişisel olarak sorumlu hissederler. Bu kişiler genellikle yüksek düzeyde performans, olumlu iş tutumları ve örgütte kalma arzusu sergilerler.

Devam bağlılığı, bireylerin örgütleriyle olan ilişkilerini, çabaları karşılığında ne aldıklarına ve ayrıldıklarında ne kaybedeceklerine (yani, ücret, yardımlar, sosyal haklar vb.) dayandırdığında ortaya çıkar. Bu kişiler, yalnızca ödüller beklentisinde olduklarından en iyi çabayı gösterirler.

Normatif bağlılık, işten çıkarılma ile ilişkili olarak, bireylerin beklenen davranış standartlarına veya toplumsal norm- 
lara bağlı olarak örgütte kalmaya zorunlu hissetmesi durumunda ortaya çıkar. Bu kişiler itaatkâr, ihtiyatlı ve formalite davranışlar gösterirler. Birey kişisel çıkarının aksine davranışlarını doğru bulduğu için örgütünde kalma davranışı gösterir.

Yakın tarihli araştırmalar örgütsel bağlıığın örgütlerin etkinliğini ve başarısını artırmak için önemli faktör olduğunu ileri sürmektedir (Eisenberger ve ark., 2010; Lub, ve ark., 2012). Bununla birlikte, nispeten az sayıda araşttrma, öğretmenler arasındaki bağııığı ele almıştır (Billingsley ve Cross, 1992). Son zamanlarda, çeşitli bağılıık yapısını (Firestone ve Rosenblum, 1988) izleme girişimleri olmasına rağmen, öğretmenlerin bağlılıları hakkındaki çalışmaların çoğu, onu genel bir yapı olarak incelemiştir (Niehoff, 1997; Reames ve Spencer, 1998). Eğitim sisteminin önemli parçalarından birisi olan öğretmenlerin içerisinde bulundukları örgütlere bağlılı̆ı son derece önemlidir. Okula bağlı olmayan öğretmenlerin, bağlıık düzeyi yüksek öğretmenlere nazaran sınıfta daha az çaba göstermeleri olasıdır. Bu durum öğrenci eğitimini ve özellikle de eğitim standartlarını olumsuz yönde etkiler.

Firestone ve Pennell (1993), öğretmen bağııığının çeşitli tanımları hakkında kapsamlı bir inceleme yapmış ve tanımların genelinde bir nesne ile bireyin psikolojik bir bağı veya kimlik tanımlaması olduğu sonucuna varmıştr. Mowday, Steers ve Porter (1979) tarafindan yaygın olarak kullanılan bir tanımlama ile tutarlı olarak, Reyes (1990), bireyin kimliğini ve belli bir organizasyona kathlımının gücünü öğretmen bağlılı̆̆ı olarak tanımlamıştır. Firestone ve Rosenblum (1988) bağııı̆ın amacının değişebileceğini belirtmişlerdir. Bunlar öğretmenlerin öğretmeye, okullarına veya öğrencilerine bağı olabilir. Son dönemlerde öğretmen bağlılığı çalışmalarında (Ebmeier, 2003; Somech ve Bogler, 2002), öğretmenlerin okullarına bağlılıkları (örgütsel bağ|ıık) ve öğretmenlik mesleği (profesyonel bağ|ılık) arasında bir ayrım yapma çabaları olmuştur.

Daha önce yapılan çalışmalar öğretmen bağıılığının olumlu sonuçlarını göstermiştir. Örneğin, Culver, Wolfe ve Cross (1990), öğretmen bağılığı ile iş tatminin pozitif ilişkili olduğunu göstermiştir. Benzer şekilde, Fresko, Kfir ve Nasser (1997) tarafindan öğretmen bağılığı ile iş tatmini arasında pozitif bir ilişki gözlemlenmiştir. Kushman (1992), öğretmenlerin örgütsel bağlılı̆ı ve okuma başarısı arasında, öğrencilerin sosyoekonomik statülerini kontrol etmede pozitif bir ilişki bulmuşlardır. Rosenholtz (1989) da bağııık ve başarı arasında pozitif bir ilişki olduğunu bildirmiştir. Öğretmen bağIılığının olumlu sonuçlarına ilişkin bu bulgular önemini ve öğretmenlerin bağlılı̆ına katkıda bulunan faktörleri belirleme ihtiyacının altını çizmektedir (Fresko ve Nasser, 1997; Riehl ve Sipple, 1996; Shann, 1998; Singh ve Billingsley, 1998).

Alan yazında örgütsel bağlılık konusuna ilişkin derleme, meta-analiz, tarama araştırmaları karşımıza çıkmasına ve alanındaki ilerlemelerin belirginleşmesine rağmen, önemli sorunların çözülmediği görülmektedir (Aydin, Sarier ve Uysal, 2011; Mathieu ve Zajac, 1990; Meyer ve Allen, 1991; Randall, 1990; Riketta, 2002). Ayrıca söz konusu meta-analiz çalışmalarının güncel olmaması, bir kısmının ilişkisel taramaların dâhil edildiği çalışmalar olması, bir kısmının örgütsel bağ|ıı̆ı tek bir değişken açısından ele alması, örgütsel bağlıık konusunda yapılan meta-analiz çalışması sayısının az olması gibi nedenler bu meta analizin yapılma gerekçesini ortaya koymaktadır.

\section{Araştırmanın Amacı ve Önemi}

Araştırmanın amacı, öğretmenlerin örgütsel bağıııklarını cinsiyet, medeni durum ve branş değişkenlerini açısından inceleyen birincil çalışmaları sentezleyerek güncel ve kapsamlı bir meta-analiz çalışması yapmak ve cinsiyet, medeni durum ve branş değişkenlerinin Türkiye'de görev yapan öğretmenlerin örgütsel bağılııları üzerindeki etkisini belirlemektir. Bu amaç doğrultusunda aşağıdaki problemlere cevap aranmıştr.

1. Türkiye'de, 2009-2017 yılları arasında, örgütsel bağlılık ile ilgili yapılan çalışmalarda cinsiyetin öğretmenlerin duygusal bağ|ılıkları, devam bağ|ılıkları, normatif bağ|ılıkları üzerindeki etki büyüklüğü nedir? Bu etki alt gruplar arasında farklılık göstermekte midir?

2. Türkiye'de, 2009-2017 yılları arasında, örgütsel bağlılık ile ilgili yapılan çalışmalarda medeni durumun öğretmenlerin duygusal bağ|ııkları, devam bağ|ı।ıkları, normatif bağ|ılıkları üzerindeki etki büyüklüğü nedir? Bu etki alt gruplar arasında farklılık göstermekte midir?

3. Türkiye'de, 2009-2017 yılları arasında, örgütsel bağlıık ile ilgili yapılan çalışmalarda branşın öğretmenlerin duygusal bağ|ılıkları, devam bağlılıkları, normatif bağlılıkları üzerindeki etki büyüklüğü nedir? Bu etki alt gruplar arasında farklılık göstermekte midir?

Örgütsel bağıııı alanında yapılan bu meta-analiz çalışması ile alana bir üst bakış açısı getirmek, yeni model ve kuramlar oluşturulmasına katkı sağlamakla beraber benzer araştırma desenlerinin ve bağımsız değişkenlerin kullanıldığı çalışmalardan elde edilen araştırma sonuçlarının bu yolla birleştirilmesinin araştırmalara dayalı olarak yapılacak yorumların daha güçlü olmasına katkı sağlayacağı düşünülmektedir. Araştırma bu bakımdan önemlidir. 


\section{Yöntem}

Bu araştrrmada; cinsiyet, medeni durum ve branş değişkenlerinin öğretmenlerin örgütsel bağlııkları üzerindeki etkisini belirlemek amacıyla, örgütsel bağlıık ile ilgili Türkiye'de yapılan araştırmaların meta analizi yapılmıştır. Meta-analiz çalışmaları, aynı ya da ilişkili amaçlarla yürütülmüş araştırmalarının birleştirilmesiyle daha genellenebilir ve birçok araştırma ile kanıtlanmış sonuçlar elde edilen araştırmalardır. Meta-analiz çalışmalarındaki mantık, aynı amaç doğrultusunda yapılan farklı çalışmaların istatistik bulguları özel yöntemlerle sentezlemek, yorumlamak ve sonuç elde etmektir (Büyüköztürk, Çakmak Kılıç, Akgün, Karadeniz ve Demirel, 2016).

\section{Verilerin Toplanması}

Araştırma problemlerine cevap verebilmek için örgütsel bağlılıkla ilgili araştırmalar Ulusal Tez Merkezi, Ulakbim veri tabanlarında ve Google Scholar akademik arama motorunda taranmıştı. Belirtilen veri tabanları ve akademik arama motorunda ilk kez 1 Kasım 2017'de tarama yapılmış; son olarak 1 Ocak 2018 tarihinde de gerekli kontroller sağlanmıştır. Araştırmaya dâhil edilen çalışmaların ekleme çıkarma kriterleri şu şekildedir:

1. 2009-2017 yılları arasında yapılan çalışmalar olması,

2. Yapılacak olan bu çalışmanın bağımsız değişkenlerinden (cinsiyet, medeni durum, branş) en az birisi üzerinde istatistiksel bulgu elde edilen tarama çalışmalar olması,

3. Allen ve Meyer (1990)' in örgütsel bağlılık sınıflandırmasını (duygusal bağılıık, devam bağ|ılığı ve normatif bağlılık) dikkate alan çalışmalar olması (Türkiye' de örgütsel bağlılık üzerine yapılan araştrmalara 1990'lı yıllardan itibaren rastlanırken, eğitim alanında 2000 yılından itibaren sıklık kazanmıştır. 2000 yılından itibaren yapılan çalışmalarda, eğitim örgütlerinin amacına ulaşmasında önemli bir etken olarak görülen öğretmenlerin, örgütsel bağlılık düzeyleri üzerine çeşitli değişkenler kullanılarak yapılan tarama araştırmaları olarak karşımıza çıkmaktadır. Bu çalışmalar sıklıkla Allen ve Meyer (1990)' in örgütsel bağlılık sınıflandırmasına dayanmaktadır. Bu nedenle bu sınıflama dikkate değer görülmüştür).

4. Eğitim alanında yapılmış ve örneklem grubunun öğretmenlerden oluşması,

5. Yurt içinde Türkçe yapılan çalışmalar olmasıdır.

Yapılacak olan meta-analiz çalışması için bu ölçütler belirlendiğinden araştırmaya dâhil edilen çalışma sayısı farkııdır. Belirlenen ölçütler paralelinde sistematik bir tarama yaklaşımı benimsenmiştir. Araştırmaların "örgütsel bağ|ııı" anahtar kelimesi kullanılarak taranması ve yukarıda belirtilen ölçütlerin uygulanması ile uygun makalelerin seçilmesi için takip edilen süreç şu şekildedir: 
"Örgütsel bağııık" anahtar kelimesi ile tarama,

Google Scholar ve Ulakbimden elde edilen makaleler $(n=7076)$.

Ulusal Tez Merkezi veri tabanından elde edilen tezler $(n=740)$

2009-2017 yılları arasında yapılan çalışmalar olması,

Google Scholar ve Ulakbimden elde edilen makaleler $(n=5285)$.

Ulusal Tez Merkezi veri tabanından elde edilen tezler $(n=603)$

Eğitim alanında yapılmış ve örneklem grubunun öğretmenlerden oluşması,

Google Scholar ve Ulakbimden elde edilen makaleler ( $\mathrm{n}=1738)$.

Ulusal Tez Merkezi veri tabanından elde edilen tezler $(n=240)$

Yurt içinde Türkçe yapılan çalışmalar olmasıdır.

\begin{tabular}{|l|}
\hline Google Scholar ve Ulakbimden elde edilen makaleler $(n=916)$. \\
Ulusal Tez Merkezi veri tabanından elde edilen tezler $(n=240)$ \\
\hline
\end{tabular}

Yapılacak olan bu çalışmanın bağımsız değişkenlerinden (cinsiyet, medeni durum, branş) en az birisi üzerinde istatistiksel bulgu elde edilen tarama çalışmalar olması,

\begin{tabular}{|c|}
\hline Google Scholar ve Ulakbimden elde edilen makaleler $(n=48)$. \\
Ulusal Tez Merkezi veri tabanından elde edilen tezler $(n=198)$ \\
\hline
\end{tabular}

Allen ve Meyer (1990)' in örgütsel bağlılık sınıflandırmasını (duygusal bağlılık, devam bağlılığı ve normatif bağııık) dikkate alan çalışmalar olması.

\section{Google Scholar ve Ulakbimden elde edilen makaleler $(n=4)$. \\ Ulusal Tez Merkezi veri tabanından elde edilen tezler $(n=19)$}

Meta-analiz sonuçları yayın yanlılığından etkilenir. Hakemler tarafindan değerlendirmesi yapılmamış, güvenirliği zayıf çalışmalar genel etkinin hesaplanmasında sıkınt oluşturur. Zaman zaman rastgele veya ciddi bir hakem değerlendirmesine tabi tutulmamış çalışmaların (bildiri, rapor vb.) analize alınması yayın yanlılığına neden olacaktır (Dinçer, 2014). Ancak bazı araştırmacılar meta-analizde dosya çekmecesi probleminin olduğunu savunur. Bu problem araştırmaların \%5 yanlış pozitif sonuçlar içerirken, geriye kalan \%95' inin anlamsız sonuçlar barındırdığı için dolap çekmecelerinde kalmak zorunda olmasından kaynaklıdır. Bu nedenle sadece yayınlanmış araştırmalara güvenmek yayın yanlılığına neden olabilecektir. Yani seçilen yayınlanmış sonuçlar istatistiksel olarak anlamlı olduğu için yanlılı̆a neden olacaktır (Rosenthal, 1979). Bu çalışmada araştırmacılar alan yazındaki bu farklı bakış açılarının farkında olarak sempozyum, kongre, vb. bilimsel etkinliklerde sunulan bildirilere yer vermemeyi tercih etmişlerdir. Yine de bu bir sınırlılık olarak düşünülebilir. Tarama çalışmalarına odaklanılmış, bağımsız değişkenleri oluşturan farklı iki grubun örgütsel bağlılık ortalamalarıyla kıyaslayıp aralarında anlamlı bir fark olup olmadığını test eden çalışmalara yoğunlaşılmıştr. Sonuç olarak belirlenen seçim kriterlerine sahip 23 (19 tez, 4 makale) dâhil edilmiştir.

\section{Dâhil Edilen Çalışmalar}

Bu çalışmada kullanılan veri toplam 23 çalışmadan elde edilmiştir. Bu çalışmalardan 19' u Yüksek Lisans tezi, 4'ü makale çalışmasıdır. Bütün araştırmalarda aynı değişkenler ele alınmadığı için cinsiyet, medeni durum ve branş değişkenleri için meta analize dâhil eden çalışma sayısı farklıdır. Meta analizde cinsiyet değişkeninin örgütsel bağııığın; duygusal bağlıık ve normatif bağ|ılık boyutuna ilişkin 19 çalışma, 8045 öğretmen; devam bağlılığı boyutuna ilişkin 18 çalışma, 7607 öğretmen yer almaktadır. Medeni durum değişkeninin örgütsel bağ|ı̆̆ın; duygusal bağ|ılık ve normatif bağılık 
boyutuna ilişkin 17 çalışma, 6098 öğretmen; devam bağlıı̆̆ı boyutuna ilişkin 16 çalışma, 5660 öğretmen yer almaktadır. Branş değişkeninin örgütsel bağııığın; duygusal bağ|ılık, devam bağlıı̆̆ı ve normatif bağ|ılık boyutuna ilişkin 7 çalışma, 2755 öğretmen yer almaktadır.

Tablo 1. Analize dâhil edilen bireysel çalışmalar

\begin{tabular}{|c|c|c|c|c|c|c|c|}
\hline \multirow{2}{*}{ Yazar (yayın yılı) } & \multirow{2}{*}{ Türü } & \multicolumn{2}{|c|}{ Cinsiyet } & \multicolumn{2}{|c|}{ Medeni Durum } & \multicolumn{2}{|c|}{ Branş } \\
\hline & & Kadın (n) & Erkek (n) & Evli (n) & Bekar (n) & $\operatorname{Sin} I f(n)$ & Branş (n) \\
\hline Akgül (2014) & Y.L. Tezi & 65 & 103 & 127 & 41 & - & - \\
\hline Akyol vd. (2012) & Makale & - & - & 215 & 85 & - & - \\
\hline Aslan (2017) & Y.L. Tezi & 315 & 293 & 169 & 439 & - & - \\
\hline Aydoğan (2010) & Y.L. Tezi & 81 & 69 & 84 & 65 & - & - \\
\hline Başyiğit (2009) & Y.L. Tezi & 187 & 134 & - & - & 158 & 147 \\
\hline Coşkun (2012) & Y.L. Tezi & 157 & 138 & 157 & 138 & 155 & 140 \\
\hline Gören (2012) & Y.L. Tezi & 303 & 272 & 506 & 69 & - & - \\
\hline Karaköse (2012) & Y.L. Tezi & 170 & 241 & - & - & - & - \\
\hline Kaygısız (2012) & Y.L. Tezi & - & - & 257 & 46 & 161 & 147 \\
\hline Kılıçoğlu (2010) & Y.L. Tezi & 341 & 143 & - & - & - & - \\
\hline Korkmaz H (2014) & Y.L. Tezi & 186 & 211 & 172 & 128 & - & - \\
\hline Korkmaz O (2014) & Y.L. Tezi & - & - & 246 & 137 & - & - \\
\hline Kurşunoğlu vd. (2010) & Makale & 238 & 115 & 303 & 50 & 166 & 187 \\
\hline Menep (2009) & Y.L. Tezi & 233 & 230 & 307 & 156 & 256 & 207 \\
\hline Özkan (2010) & Y.L. Tezi & 407 & 315 & - & - & 352 & 371 \\
\hline Selçuklu (2013) & Y.L. Tezi & - & - & 159 & 108 & - & - \\
\hline Serdaroğlu (2013) & Makale & 153 & 111 & - & - & - & - \\
\hline Sönmez (2016) & Y.L. Tezi & 128 & 78 & 117 & 70 & - & - \\
\hline Uştu (2014) & Y.L. Tezi & 336 & 370 & 450 & 262 & - & - \\
\hline Uysal (2014) & Y.L. Tezi & 132 & 266 & 360 & 30 & - & - \\
\hline Vurdu (2017) & Y.L. Tezi & 211 & 98 & 134 & 74 & 30 & 278 \\
\hline Yalçın (2009) & Y.L. Tezi & 149 & 289 & 378 & 59 & - & - \\
\hline Yörük ve Sağban (2012) & Makale & 352 & 425 & - & - & - & - \\
\hline Toplam & & 4144 & 3901 & 4141 & 1957 & 1278 & 1477 \\
\hline
\end{tabular}

\section{Verilerin Kodlanması}

Çalışma verilerini toplamak için alan yazından faydalanılarak araştırmacılar tarafindan veri kodlama formu geliştirilmiştir. Veri kodlama formunda bireysel araştırmaların etki büyüklüğünü hesaplamak için gereken istatistiksel veriler ve araştırma özellikleri (yöntem, örneklem, ölçüm aracı, yayın türü vb) sorgulanmıştır. Bireysel araştırmalar için çalışmanın başlı̆ıı, yazarı, yayın yılı, yayın türü, örneklem büyüklüğü, yayın dili; örgütsel bağıılı̆ı ölçmek için kullanılan ölçüm aracı ve cinsiyete, medeni duruma ve branşa göre öğretmenlerin örgütsel bağlılık düzeyi kodlanmıştır. Kodlanan verilerin güvenirliğini sağlamak için araştırmacıların kodlamaları karşılaştırılmıştır. Etki büyüklüğü değerinin pozitif olması; kadınların erkeklerden, evlilerin-bekarlardan, branş öğretmenlerinin sınıf öğretmenlerinden örgütsel bağılık puanının daha yüksek olduğunu; negatif olması ise erkeklerin kadınlardan, bekarların evlilerden, sınıf öğretmenlerinin branş öğretmenlerinden daha yüksek olduğunu göstermektedir.

\section{Verilerin Analizi}

Elde edilen veriler Comprehensive Meta-Analysis 3.0 (CMA) paket programı kullanılarak analiz edilmiştir. Çalışmanın meta-analizine dâhil edilen araştırmaların etki büyüklüklerini hesaplayabilmek için çalışmaların bulgularında yer alan $n$, $x, t$ ve $p$ değerlerinden yararlanılmışttr.

Araştırmanın yayın yanlılığını test etmek için ilk olarak huni grafiğine bakılmıştr. Araştırma problemleri doğrultusunda (cinsiyet, medeni durum ve branş değişkenlerinin her biri için örgütsel bağlılığın duygusal, devam ve normatif bağlılık boyutunda) toplam 9 huni grafiği incelenmiştir. İncelenen grafikte bireysel çalışmaların çok büyük bir bölümü huni grafiğinin içinde ve simetrik bir biçimdedir. Ayrıca alan yazında (Borenstein, Hedges, Higgins, ve Rothstein 2009; Dinçer, 2014) huni grafikleri yayın yanlııı̆ını kontrol etmek için en sık kullanılan yöntem olduğu ancak daha detaylı bir inceleme için Classic fail-safe $\mathrm{N}$ istatistiğine bakılabileceği belirtilmiştir. Bu bakımdan ikinci olarak cinsiyet, medeni durum ve branş değişkenleri için duygusal bağ|ılık, devam bağlıı̆̆ı ve normatif bağlılık boyutlarında Rosenthal'ın korumalı 
n' i (fail-safe $n$ ) hesaplanmıştır. Bu çalışmada, yayın yanlılı̆ından olabildiğince uzak durmak açısından FSN'nin hangi sınırı aşması gerektiği ile ilgili kesin bir kural olmamasından, Mullen, Muellerleile ve Bryant (2001) ile Rosenthal'ın (1979) önerisi esas alınarak, N/ $(5 k+10)$ ( $k=$ meta-analize dâhil edilen çalışma sayısıdır) değerinin 1 sınırını geçmesi gerektiği öngörülmüştür. Buna göre cinsiyet açısından; duygusal bağ|ı।ık boyutunda $F S N=142$, (N/ $(5 k+10)$ oranı 1.35, devam bağlılı̆ı boyutunda FSN=139, (N/ (5k+10) oranı 1.39, normatif bağlılık boyutunda $F S N=212$, (N/ $(5 k+10)$ oranı 2.12 olarak hesaplanmıştır. Medeni durum açısından; duygusal bağ|ıık boyutunda FSN=98, (N/ $(5 k+10)$ oranı 1.03, devam bağ|ı̆ğı boyutunda FSN=151, (N/ (5k+10) oranı 1.67, normatif bağlılık boyutunda FSN=171, (N/ $(5 k+10)$ oranı 1.95 olarak hesaplanmıştır. Branş açısından; duygusal bağlıık boyutunda $\mathrm{FSN}=58$, (N/ $(5 \mathrm{k}+10)$ oranı 1.28, devam bağılığı boyutunda $\mathrm{FSN}=57,(\mathrm{~N} /(5 \mathrm{k}+10)$ oranı 1.26, normatif bağlılık boyutunda FSN= 53, (N/ $(5 \mathrm{k}+10)$ oranı 1.17 olarak hesaplanmıştr. Elde edilen değerler yayın yanlılığııın olmadığını göstermektedir.

Çalışmanın istatistiğinde etki büyüklüğü değerleri hesaplanmıştır. Bu hesaplama Hedges ve Olkin (1985) tarafindan önerilen Hedges' g hesaplamasına göre yapılmıştı. Çalışmaların etkisi üzerinde sınıflandırma yapılırken geniş ölçekli Thalheimer ve Cook (2002) tarafindan aşağıda belirtilen düzey sınıflamasına göre, genel etki büyüklüğü ve homojenlik testi için Hedges' g kullanılmıştir.

$-0,15 \leq$ etki katsayısı (g ya da d) $<0,15$ önemsiz düzeyde,

$0,15 \leq$ etki katsayısı (g ya da d) $<0,40$ küçük düzeyde,

$0,40 \leq$ etki katsayısı ( $g$ ya da d) $<0,75$ orta düzeyde,

$0,75 \leq$ etki katsayısı ( $g$ ya da $\mathrm{d}$ ) $<1,10$ geniş düzeyde,

$1,10 \leq$ etki katsayısı ( $g$ ya da $\mathrm{d}$ ) $<1,45$ çok geniş düzeyde,

$1,45 \leq$ etki katsayısı ( $g$ ya da d) mükemmel düzeyde

Genel etkinin hesaplanması için ilk olarak yayın yanlılığı istatistiğine bakılmış, ikinci olarak heterojenlik testi yapılmıştr. Sonrasında ise Hedges ve Vevea' nın (1998) modeller arasındaki kavramsal farkı açıklamayı amaçladığı görüşüne dayanılarak uygun modele karar verilirken en önemli meselenin yapılmak istenen çıkarımın sonuçları olduğu göz önünde bulundurularak sabit etki modeli veya rastgele etkiler modeline göre analiz sonuçları değerlendirilmiştir.

\section{Bulgular}

Cinsiyet, medeni durum ve branş değişkenlerinin öğretmenlerin örgütsel bağılılkları üzerindeki etkisini ortaya koymayı hedefleyen bu meta-analizde dahil etme kriterlerini karşılayan 23 bağımsız çalışma ve bu çalışmalara ait 127 etki büyüklüğü kullanılmıştr. Meta-analizde hangi modelin kullanılacağına karar verebilmek için $Q$ istatistiği öncelikle hesaplanmış, I ${ }^{2}$ değeri saptanmış ve $p$ değerleri incelenmiştir. Sonrasında uzman görüşünden de yararlanılmıştır.

\section{Birinci alt probleme ilişkin bulgular}

Cinsiyetin, öğretmenlerin örgütsel bağ|ılığının duygusal bağ|ılık, devam bağ|ılığı ve normatif bağ|ılıkları üzerindeki etkisini ortaya çıkaran meta-analiz sonuçları Tablo 2'de sunulmuştur.

Tablo 2. Etki modellerine göre meta-analiz çalışması sonuçlarının karşılaştırılması (Cinsiyet).

\begin{tabular}{|c|c|c|c|c|c|c|c|c|c|c|}
\hline \multirow{2}{*}{$\begin{array}{l}\text { Örgütsel } \\
\text { Bağ|ılık }\end{array}$} & \multirow{2}{*}{ Model } & \multirow{2}{*}{ df } & \multirow{2}{*}{$\mathrm{z}$} & \multirow{2}{*}{$p$} & \multirow{2}{*}{$1^{2}$} & \multirow{2}{*}{ Q } & \multirow{2}{*}{$\begin{array}{c}\text { Ki Kare tablo } \\
\text { değeri }\end{array}$} & \multirow{2}{*}{ ES } & \multicolumn{2}{|c|}{ Güven Aralığı } \\
\hline & & & & & & & & & Alt Sınır & Üst Sınır \\
\hline Duygusal & Sabit Etkiler Modeli & 18 & $-4,575$ & 0,000 & & 44,454 & 28,809 & $-0,104$ & $-0,149$ & $-0,060$ \\
\hline Bağlılık & Rastgele Etkiler Modeli & 18 & $-3,097$ & 0,002 & 59,509 & 44,454 & 28,809 & $-0,114$ & $-0,186$ & $-0,042$ \\
\hline Devam & Sabit Etkiler Modeli & 17 & $-3,081$ & 0,002 & & 10,965 & 27,587 & $-0,072$ & $-0,118$ & $-0,026$ \\
\hline Bağ|ılığı & Rastgele Etkiler Modeli & 17 & $-3,081$ & 0,002 & 0,000 & 10,965 & 27,587 & $-0,072$ & $-0,118$ & $-0,026$ \\
\hline Normatif & Sabit Etkiler Modeli & 18 & $-5,269$ & 0,000 & & 83,528 & 28,809 & $-0,123$ & $-0,169$ & $-0,077$ \\
\hline Bağlılık & Rastgele Etkiler Modeli & 18 & $-2,878$ & 0,004 & 79,648 & 83,528 & 28,809 & $-0,153$ & $-0,257$ & $-0,049$ \\
\hline
\end{tabular}

Cinsiyetin, öğretmenlerin örgütsel bağ|ılığının duygusal bağlılık boyutu üzerindeki etkisini ortaya çıkaran meta-analiz sonuçları

Homojenlik testi sonucunda cinsiyet değişkeni için örgütsel bağlılığın duygusal bağ|ılık boyutu için Q istatistiksel değeri 44,454 olarak hesaplanmıştr. Ki-kare tablosundan \%95 anlamlılık düzeyinde 18 serbestlik derecesi ile kritik değer 28,809 olarak kabul edilmektedir. Bu araşttrmada hesaplanan $Q$ istatistiksel değeri $(44,454)$, kritik değer olan 28,809 'ten büyüktür. Ayrıca I '2değeri çalışmadaki değişkenliklerin gerçek heterojenliği ile etki büyüklüğü dizisindeki toplam değişkenliklerin yüzdesi olarak yorumlanır ve heterojenliği daha hassas ölçebilir(Huedo-Medina vd., 2006). Hi- 
ggins ve Thompson (2002) $I^{2}$ değerleri sınıflamasına göre \%25 $\left(I^{2}=25\right)$ düşük, \%50 $\left(I^{2}=50\right)$ orta ve $\% 75\left(I^{2}=75\right)$ yüksek düzeyde heterojenlik olarak yorumlanır. Cinsiyet değişkeni için örgütsel bağıılığın duygusal bağlılık boyutu için $I^{2}$ değerinin \%59,509 olduğu görülmektedir. Bu değer, gerçek heterojenliğin veya çalışmalar arasındaki değişkenliğe atfedilebilecek toplam değişkenliğin yüzdesinin $\% 59,50$ olduğunu gösterir. Farklı bir ifade ile varyansın \%59,50 çalışmalar arasındaki, \%40,50'si ise tesadüfi hataya dayalı olarak çalışma içinde bulunan varyanstır. Bunun yanında p değeri ( .002) $p=.05$ 'ten küçüktür. Tüm bu değerler $\left(Q=44,454, p<.05,\left.\right|^{2}=59,509\right)$ etki büyüklükleri arasında heterojen bir dağııım olduğunu ve etki büyüklüklerinin yorumlanmasında rastgele etkiler modelinin kullanılması gerektiğini göstermektedir.

Cinsiyet değişkeninin örgütsel bağlılı̆ın duygusal bağ|ılık boyutunda araştırmaya dahil edilen 19 çalışmanın ortalama etki büyüklüğü hesaplandığında, \% 95'lik güven aralığının -0,186 alt sınıı ile -0,042 üst sınırında ortalama etki büyüklüğü $E S=-0,114$ olarak cinsiyete göre örgütsel bağ|ıı̆̆ın duygusal bağ|ıık boyutunda erkek öğretmenlerin kadın öğretmenlere göre daha fazla duygusal bağlılık yaşadığı görülmüştür. Thalheimer ve Cook (2002) tarafindan belirtilen düzey sınıflamasına göre, etki büyüklüğü değerinin önemsiz bir etkiye sahip olduğu belirlenmiştir.

Cinsiyet değişkenine göre hesaplanan etki değerlerine araştırma türü ve yılı değişkenlerinin ara değişken etkisi de incelenmiştir. Araştrma türü ara değişkenleri tez $(n=16)$ ve makale $(n=3)$ olarak iki gruba ayrılmıştr. Araştırma türü gruplarına ait etki büyüklükleri tez türündeki çalışmalar için -0.123, makaleler türündeki çalışmalar için -0.096 olarak hesaplanmıştr. Araştırma türü ara değişkeni için çalışmalar arası varyans istatistiksel olarak anlamlı değildir. Çalışmaların makale ya da tez olması cinsiyet değişkenine göre öğretmenlerin örgütsel bağlılı̆ın duygusal bağlılık boyutuna ilişkin etki büyüklüğünü değiştirmektedir.

Yayın yılı ara değişkenleri $2009(n=3), 2010(n=4), 2012(n=4), 2014(n=4), 2017(n=2)$ olarak beş gruba ayrılmıştır. Ancak yayın sayısının azlığı nedeniyle 2013 ve 2016 yılında yapılan iki araştırma değerlendirmeye alınmamıştır. Yayın yılı kategorilerine ait etki büyüklükleri 2009 yılı için -0.024, 2010 yılı için $-0,150,2012$ yılı için -0,084, 2014 yılı için -0,102, 2017 yılı için $-0,390$ olarak hesaplanmıştır. Yayın yılı ara değişkeni için çalışmalar arası varyans istatistiksel olarak anlamlı değildir. Çalışmaların farklı yıllarda yapılmış olması cinsiyet değişkenine göre öğretmenlerin örgütsel bağlılığın duygusal bağ|ıık boyutuna ilişkin etki büyüklüğünü değiştirmemektedir.

\begin{tabular}{|c|c|c|c|c|c|c|c|c|c|c|c|c|c|}
\hline \multirow[t]{2}{*}{ Model } & \multirow[t]{2}{*}{ Study name } & \multicolumn{7}{|c|}{ Statistics for each study } & \multicolumn{5}{|c|}{ Hedges's $\mathrm{g}$ and $95 \% \mathrm{Cl}$} \\
\hline & & Hedges's g & $\begin{array}{l}\text { Standard } \\
\text { error }\end{array}$ & Variance & Lower limit & Upper limit & ZVValue & p.Value & $-0,50$ & $-0,25$ & 0,00 & 0,25 & 0.50 \\
\hline & Akgiil 2014 & $-0,081$ & 0.158 & 0,025 & $\cdot 0,390$ & 0.229 & $\cdot 0,511$ & 0,609 & & & & & \\
\hline & Aslan 2017 & $\cdot 0,055$ & 0,081 & 0,007 & $-0,214$ & 0,104 & $.0,680$ & 0,497 & & & & & \\
\hline & Aydoğan 2010 & $.0,038$ & 0,163 & 0,027 & $\cdot 0,357$ & 0,282 & $\cdot 0,231$ & 0,817 & & & & & \\
\hline & Basyiğit 2009 & $.0,034$ & 0,113 & 0,013 & $-0,255$ & 0,187 & $\cdot 0,301$ & 0,763 & & & & & \\
\hline & Coşkun 2012 & $-0,100$ & 0,116 & 0,014 & $\cdot 0,328$ & 0,128 & $-0,859$ & 0,390 & & & & & \\
\hline & Gören 2012 & $-0,150$ & 0,084 & 0,007 & $-0,314$ & 0,014 & $-1,797$ & 0,072 & & & & & \\
\hline & Karaköse 2012 & $-0,043$ & 0,100 & 0,010 & $\cdot 0,239$ & 0,153 & $-0,432$ & 0,666 & & & & & \\
\hline & Kulıçoğlu 2010 & $-0,160$ & 0,100 & 0.010 & $-0,355$ & 0,035 & $-1,604$ & 0,109 & & & & & \\
\hline & Korkmaz 2014 & $\cdot 0,147$ & 0.101 & 0.010 & $-0,344$ & 0.050 & $-1,458$ & 0.145 & & & & & \\
\hline & Kurşunoğlu Bakay Tanrioğen 2010 & $\cdot 0,180$ & 0,114 & 0.013 & $\cdot 0,402$ & 0,043 & $-1,584$ & 0.113 & & & & & \\
\hline & Menep 2009 & 0,089 & 0,093 & 0,009 & $.0,093$ & 0.271 & 0.961 & 0,337 & & & & & \\
\hline & Özkan 2010 & $-0,054$ & 0,075 & 0.006 & $-0,201$ & 0,093 & $.0,720$ & 0.472 & & & & & \\
\hline & Serdaroğlu 2013 & $.0,077$ & 0.124 & 0.015 & $-0,321$ & 0,167 & $.0,621$ & 0,535 & & & & & \\
\hline & Sinan Şöhret Sağban 2012 & 0,004 & 0,072 & 0,005 & $\cdot 0,138$ & 0,145 & 0,050 & 0,960 & & & & & \\
\hline & Sönmez 2016 & 0,118 & 0,143 & 0,021 & $\cdot 0,162$ & 0,399 & 0.827 & 0,408 & & & & & \\
\hline & Uş̧tu 2014 & $-0,164$ & 0,075 & 0,006 & $\cdot 0,311$ & $.0,016$ & $\cdot 2,177$ & 0,029 & & & & & \\
\hline & Uysal 2014 & $\cdot 0,096$ & 0,106 & 0,011 & $-0,304$ & 0,112 & $\cdot 0.903$ & 0,367 & & & & & \\
\hline & Vurdu 2017 & $-0,048$ & 0,122 & 0,015 & $-0,288$ & 0,192 & $\cdot 0,395$ & 0,693 & & & & & \\
\hline Fixed & & $-0,072$ & 0.023 & 0,001 & $-0,118$ & $-0,026$ & $-3,080$ & 0,002 & & & + & & \\
\hline Random & & $-0,072$ & 0,023 & 0,001 & $.0,118$ & $.0,026$ & $-3,080$ & 0,002 & & & + & & \\
\hline
\end{tabular}

Şekil 1.Cinsiyetin, öğretmenlerin örgütsel bağlılığının duygusal bağlılık boyutu üzerindeki etkisini gösteren orman grafiği

Cinsiyetin, öğretmenlerin örgütsel bağlılığının devam bağlıı̆̆ı boyutu üzerindeki etkisini ortaya çıkaran meta-analiz sonuçları

Homojenlik testi sonucunda cinsiyet değişkeni için örgütsel bağlılı̆ın devam bağlılığı boyutu için Q istatistiksel değeri 10,965 olarak hesaplanmıştır. Ki-kare tablosundan \%95 anlamlılık düzeyinde 17 serbestlik derecesi ile kritik değer 27,587 olarak kabul edilmektedir. Bu araştırmada hesaplanan Q istatistiksel değeri (10,965), kritik değer olan 27,587'ten küçüktür. Cinsiyet değişkeni için örgütsel bağlılığın devam bağlılığı boyutu için I ${ }^{2}$ değerinin $\% 0,00$ olduğu görülmektedir. Bunun yanında $p$ değeri (.002) $p=.05^{\prime}$ ten küçüktür. Tüm bu değerler $\left(Q=27,587, p<.05, I^{2}=0,000\right)$ homojenliğe işaret etmektedir. Etki büyüklüklerinin yorumlanmasında sabit etkiler modelinin kullanılması gerekir.

Cinsiyet değişkeninin örgütsel bağ|ılığın devam bağlılığı boyutunda araştırmaya dahil edilen 18 çalışmanın ortalama 
etki büyüklüğü hesaplandığında, \% 95'lik güven aralığının -0,118 alt sınırı ile -0,026 üst sınırında ortalama etki büyüklüğü $E S=-0,072$ olarak cinsiyete göre örgütsel bağlılığın devam bağlılı̆ı boyutunda erkek öğretmenlerin kadın öğretmenlere göre daha fazla devam bağlılı̆ı yaşadığı görülmüştür. Thalheimer ve Cook (2002) tarafindan belirtilen düzey sınıflamasına göre, etki büyüklüğü değerinin önemsiz bir etkiye sahip olduğu belirlenmiştir.

\begin{tabular}{|c|c|c|c|c|c|c|c|c|c|c|c|c|c|}
\hline \multirow[t]{2}{*}{ Model } & \multirow[t]{2}{*}{ Study name } & \multicolumn{7}{|c|}{ Statistics for each study } & \multicolumn{5}{|c|}{ Hedges's $\mathrm{g}$ and $95 \% \mathrm{Cl}$} \\
\hline & & Hedges's g & $\begin{array}{l}\text { Standard } \\
\text { error }\end{array}$ & Variance & Lower limit & Upper limit & ZValue & p.Value & $-1,00$ & $\cdot 0,50$ & 0,00 & 0,50 & 1,00 \\
\hline & Akgiul 2014 & $-0,047$ & 0,158 & 0,025 & $.0,356$ & 0.262 & $.0,298$ & 0,766 & & & & & \\
\hline & Aslan 2017 & $.0,045$ & 0,081 & 0,007 & $.0,204$ & 0,114 & $.0,560$ & 0,576 & & & $\longrightarrow$ & & \\
\hline & Aydoğan 2010 & $.0,155$ & 0,163 & 0,027 & $\cdot 0,475$ & 0,165 & $\cdot 0,951$ & 0,342 & & & & & \\
\hline & Basyigigit 2009 & $.0,074$ & 0,113 & 0,013 & $.0,296$ & 0,147 & $-0,658$ & 0,511 & & & & & \\
\hline & Coskun 2012 & $.0,001$ & 0,116 & 0,014 & $.0,229$ & 0,227 & $-0,006$ & 0,995 & & & & & \\
\hline & Gören 2012 & $-0,233$ & 0,084 & 0,007 & $-0,397$ & $.0,069$ & $-2,781$ & 0,005 & & & ᄂ & & \\
\hline & Karaköse 2012 & $.0,155$ & 0,100 & 0,010 & $.0,351$ & 0,042 & $-1,544$ & 0,123 & & & & & \\
\hline & Kiliçoğlu 2010 & $.0,086$ & 0,100 & 0,010 & $.0,281$ & 0,109 & $-0,866$ & 0,387 & & & $\longrightarrow$ & & \\
\hline & Korkmaz 2014 & $.0,142$ & 0,101 & 0,010 & $.0,339$ & 0,055 & $-1,410$ & 0.158 & & & & & \\
\hline & Kurşunoğlu Bakay Tanniöğen 2010 & $.0,160$ & 0,113 & 0,013 & $.0,382$ & 0,063 & $-1,408$ & 0,159 & & & & & \\
\hline & Menep 2009 & 0,037 & 0,093 & 0,009 & $-0,145$ & 0,219 & 0,400 & 0,689 & & & & & \\
\hline & Özkan 2010 & $.0,200$ & 0,075 & 0,006 & $.0,347$ & $.0,052$ & $-2,656$ & 0,008 & & & - & & \\
\hline & Serdaroğlu 2013 & $.0,180$ & 0,125 & 0,016 & $-0,424$ & 0,064 & $-1,443$ & 0,149 & & & & & \\
\hline & Sinan Şöhret Sağban 2012 & 0,052 & 0,072 & 0,005 & $.0,089$ & 0,193 & 0,720 & 0,472 & & & & & \\
\hline & Sönmez 2016 & 0,120 & 0,143 & 0,021 & $-0,160$ & 0,401 & 0,840 & 0,401 & & & & & \\
\hline & Uş̧tu 2014 & $.0,007$ & 0,075 & 0,006 & $.0,154$ & 0,140 & $.0,097$ & 0,923 & & & — & & \\
\hline & Uysal 2014 & $.0,212$ & 0,107 & 0,011 & $.0,421$ & $.0,004$ & $.1,993$ & 0,046 & & & - & & \\
\hline & Vurdu 2017 & $.0,736$ & 0,126 & 0,016 & $-0,983$ & $-0,489$ & $-5,847$ & 0,000 & & & & & \\
\hline & Yalçin 2009 & $.0,035$ & 0,101 & 0,010 & $.0,233$ & 0,162 & $-0,350$ & 0,726 & & & 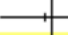 & & \\
\hline Fixed & & $-0,104$ & 0,023 & 0,001 & $\cdot 0,149$ & $.0,060$ & $-4,575$ & 0,000 & & & + & & \\
\hline Random & & $.0,114$ & 0,037 & 0,001 & $.0,186$ & $.0,042$ & $-3,097$ & 0,002 & & & + & & \\
\hline
\end{tabular}

Şekil 2.Cinsiyetin, öğretmenlerin örgütsel bağlılığının devam bağlılığı boyutu üzerindeki etkisini gösteren orman grafiği

Cinsiyetin, öğretmenlerin örgütsel bağııı̆̆ının normatif bağlılık boyutu üzerindeki etkisini ortaya çıkaran meta-analiz sonuçları

Homojenlik testi sonucunda cinsiyet değişkeni için örgütsel bağlıı̆ın normatif bağılık boyutu için $Q$ istatistiksel değeri 83,528 olarak hesaplanmıştir. Ki-kare tablosundan \%95 anlamlılık düzeyinde 18 serbestlik derecesi ile kritik değer 28,809 olarak kabul edilmektedir. Bu araşttrmada hesaplanan $Q$ istatistiksel değeri $(83,528)$, kritik değer olan 28,809'ten büyüktür. Cinsiyet değişkeni için örgütsel bağ|ılığın normatif bağlılık boyutu için I ${ }^{2}$ değerinin \%79,648 olduğu görülmektedir. Bunun yanında $p$ değeri $(.002) p=.05^{\prime}$ ten küçüktür. Tüm bu değerler $\left(Q=83,528, p<.05, I^{2}=79,648\right)$ etki büyüklükleri arasında heterojen bir dağılım olduğunu ve etki büyüklüklerinin yorumlanmasında rastgele etkiler modelinin kullanılması gerektiğini göstermektedir.

Cinsiyet değişkeninin örgütsel bağlılı̆ın normatif bağlılık boyutunda araştırmaya dahil edilen 18 çalışmanın ortalama etki büyüklüğü hesaplandığında, \% 95'lik güven aralığının -0,257 alt sınıı ile -0,049 üst sınırında ortalama etki büyüklüğü $E S=-0,153$ olarak cinsiyete göre örgütsel bağlıığın normatif bağlıık boyutunda erkek öğretmenlerin kadın öğretmenlere göre daha fazla normatif bağlılık yaşadığı görülmüştür. Thalheimer ve Cook (2002) tarafindan belirtilen düzey sınıflamasına göre, etki büyüklüğü değerinin önemsiz bir etkiye sahip olduğu belirlenmiştir.

Cinsiyet değişkenine göre hesaplanan etki değerlerine araştırma türü ve yılı değişkenlerinin ara değişken etkisi de incelenmiştir. Araştrma türü ara değişkenleri tez $(n=15)$ ve makale $(n=3)$ olarak iki gruba ayrılmıştr. Araştırma türü gruplarına ait etki büyüklükleri tez türündeki çalışmalar için -0.164 , makaleler türündeki çalışmalar için -0.145 olarak hesaplanmıştr. Araştırma türü ara değişkeni için çalışmalar arası varyans istatistiksel olarak anlamlı değildir. Çalışmaların makale ya da tez olması cinsiyet değişkenine göre öğretmenlerin örgütsel bağ|ıığın normatif bağlılık boyutuna ilişkin etki büyüklüğünü değiştirmektedir.

Yayın yılı ara değişkenleri $2009(n=2), 2010(n=4), 2012(n=4), 2014(n=4), 2017(n=2)$ olarak beş gruba ayrılmıştır. Ancak yayın sayısının azlığı nedeniyle 2013 ve 2016 yılında yapılan iki araştırma değerlendirmeye alınmamıştır. Yayın yııı kategorilerine ait etki büyüklükleri 2009 yılı için -0,007, 2010 yılı için -0,203, 2012 yılı için -0,088, 2014 yılı için -0,128, 2017 yılı için $-0,581$ olarak hesaplanmıştr. Yayın yılı ara değişkeni için çalışmalar arası varyans istatistiksel olarak anlamlı değildir. Çalışmaların farklı yıllarda yapılmış olması cinsiyet değişkenine göre öğretmenlerin örgütsel bağlılı̆ın normatif bağlılık boyutuna ilişkin etki büyüklüğünü değiştirmemektedir. 


\begin{tabular}{|c|c|c|c|c|c|c|c|c|c|c|c|c|c|}
\hline \multirow[t]{2}{*}{ Model } & \multirow[t]{2}{*}{ Study name } & \multicolumn{7}{|c|}{ Statistics for each study } & \multicolumn{5}{|c|}{ Hedges's $\mathrm{g}$ and $95 \% \mathrm{Cl}$} \\
\hline & & Hedges's g & $\begin{array}{l}\text { Standard } \\
\text { error }\end{array}$ & Variance & Lower limit & Upper limit & $Z$ Value & p.Value & $\cdot 2,00$ & $-1,00$ & 0,00 & 1,00 & 2,00 \\
\hline & A.kguil 2014 & $.0,066$ & 0,158 & 0,025 & $-0,375$ & 0.243 & $\cdot 0,419$ & 0.675 & & & 4 & & \\
\hline & Aslan 2017 & $.0,043$ & 0,081 & 0,007 & $-0,202$ & 0,116 & $.0,530$ & 0,596 & & & $\rightarrow$ & & \\
\hline & Aydoğan 2010 & $.0,283$ & 0,164 & 0,027 & $.0,604$ & 0,038 & $-1,725$ & 0,084 & & & 一 & & \\
\hline & Başyiğit 2009 & $.0,137$ & 0,113 & 0,013 & $-0,358$ & 0,085 & $-1,209$ & 0.227 & & & $\rightarrow$ & & \\
\hline & Coşkun 2012 & $.0,043$ & 0,116 & 0,014 & $\cdot 0,271$ & 0,185 & $\cdot 0,369$ & 0,712 & & & $\longrightarrow$ & & \\
\hline & Gören 2012 & $.0,089$ & 0,083 & 0,007 & $-0,253$ & 0,074 & $\cdot 1,069$ & 0,285 & & & $\rightarrow$ & & \\
\hline & Karaköse 2012 & $.0,238$ & 0,100 & 0,010 & $-0,435$ & $\cdot 0,041$ & $\cdot 2,373$ & 0,018 & & & $\rightarrow$ & & \\
\hline & Kuliçoğlu 2010 & $.0,046$ & 0,099 & 0,010 & $-0,241$ & 0,149 & $-0,459$ & 0.646 & & & $\rightarrow$ & & \\
\hline & Korkmaz 2014 & $.0,192$ & 0,101 & 0,010 & $-0,389$ & 0,005 & $-1,906$ & 0,057 & & & $\longrightarrow$ & & \\
\hline & Kurşunoğlu Bakay Tanriöğen 2010 & $.0,301$ & 0,114 & 0,013 & $\cdot 0,525$ & $.0,078$ & $\cdot 2,647$ & 0,008 & & & $\longrightarrow$ & & \\
\hline & Menep 2009 & 0,152 & 0,093 & 0,009 & $-0,030$ & 0,334 & 1,638 & 0,102 & & & & & \\
\hline & Özkan 2010 & $.0,183$ & 0,075 & 0,006 & $-0,330$ & $.0,035$ & $\cdot 2,432$ & 0.015 & & & + & & \\
\hline & Serdaroğlu 2013 & $.0,151$ & 0,124 & 0,015 & $-0,395$ & 0,093 & $\cdot 1,212$ & 0.225 & & & $\rightarrow$ & & \\
\hline & Sinan Şöhret Sağban 2012 & 0,017 & 0,072 & 0,005 & $-0,125$ & 0,158 & 0,230 & 0,818 & & & & & \\
\hline & Sönmez 2016 & 0,077 & 0,143 & 0,020 & $-0,203$ & 0,358 & 0,540 & 0,589 & & & - & & \\
\hline & Uş̧u 2014 & $.0,028$ & 0.075 & 0,006 & $\cdot 0,175$ & 0.119 & $.0,378$ & 0,705 & & & - & & \\
\hline & Uysal 2014 & $\cdot 0,226$ & 0,107 & 0,011 & $-0,435$ & $\cdot 0,017$ & $\cdot 2,123$ & 0,034 & & & + & & \\
\hline & Vurdu 2017 & $-1,119$ & 0,130 & 0,017 & $-1,374$ & $-0,863$ & $\cdot 8,578$ & 0,000 & & 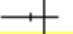 & & & \\
\hline Fixed & & $-0,123$ & 0,023 & 0,001 & $-0,169$ & $\cdot 0,077$ & $-5,269$ & 0.000 & & & + & & \\
\hline Random & & $-0,153$ & 0,053 & 0,003 & $-0,257$ & $.0,049$ & $\cdot 2,878$ & 0,004 & & & + & & \\
\hline
\end{tabular}

Şekil 3.Cinsiyetin, öğretmenlerin örgütsel bağlılığının normatif bağlılık boyutu üzerindeki etkisini gösteren orman grafiği

\section{İkinci alt probleme ilişkin bulgular}

Medeni durumun, öğretmenlerin örgütsel bağlılığının duygusal bağlılık, devam bağlılığı ve normatif bağ|ılıkları üzerindeki etkisini ortaya çıkaran meta-analiz sonuçları Tablo 3'te sunulmuştur.

Tablo 3. Etki modellerine göre meta-analiz çalışması sonuçlarının karşılaştırılması (Medeni Durum)

\begin{tabular}{|c|c|c|c|c|c|c|c|c|c|c|}
\hline \multirow{2}{*}{$\begin{array}{l}\text { Örgütsel } \\
\text { Bağlılık }\end{array}$} & \multirow{2}{*}{ Model } & \multirow{2}{*}{$d f$} & \multirow{2}{*}{ Z } & \multirow{2}{*}{$p$} & \multirow{2}{*}{$1^{2}$} & \multirow{2}{*}{ Q } & \multirow{2}{*}{$\begin{array}{c}\text { Ki Kare tablo } \\
\text { değeri }\end{array}$} & \multirow{2}{*}{ ES } & \multicolumn{2}{|c|}{ Güven Aralığı } \\
\hline & & & & & & & & & Alt Sınır & Üst Sınır \\
\hline Duygusal & Sabit Etkiler Modeli & 16 & $-3,801$ & 0,000 & & 25,135 & 26,296 & $-0,111$ & $-0,169$ & $-0,054$ \\
\hline Bağlılık & Rastgele Etkiler Modeli & 16 & $-3,268$ & 0,001 & 36,345 & 25,135 & 26,296 & $-0,124$ & $-0,198$ & $-0,050$ \\
\hline Devam & Sabit Etkiler Modeli & 15 & $-2,287$ & 0,022 & & 10,965 & 24,996 & $-0,069$ & $-0,127$ & $-0,010$ \\
\hline Bağ|ılığı & Rastgele Etkiler Modeli & 15 & $-2,287$ & 0,022 & 0,000 & 10,965 & 24,996 & $-0,069$ & $-0,127$ & $-0,010$ \\
\hline Normatif & Sabit Etkiler Modeli & 16 & $-3,727$ & 0,000 & & 14,593 & 26,296 & $-0,109$ & $-0,167$ & $-0,052$ \\
\hline Bağlılık & Rastgele Etkiler Modeli & 16 & $-3,727$ & 0,000 & 0,000 & 14,593 & 26,296 & $-0,109$ & $-0,167$ & $-0,052$ \\
\hline
\end{tabular}

Medeni durumun, öğretmenlerin örgütsel bağlılı̆ının duygusal bağlılık boyutu üzerindeki etkisini ortaya çıkaran meta-analiz sonuçları

Homojenlik testi sonucunda medeni durum değişkeni için örgütsel bağlıı̆̆ın duygusal bağlılık boyutu için $Q$ istatistiksel değeri 25,135 olarak hesaplanmıştr. Ki-kare tablosundan \%95 anlamlılık düzeyinde 16 serbestlik derecesi ile kritik değer 26,296 olarak kabul edilmektedir. Bu araştrmada hesaplanan $Q$ istatistiksel değeri $(25,135)$, kritik değer olan 26,296 sınırda küçüktür. Medeni durum değişkeni için örgütsel bağ|ılığın duygusal bağ|ılık boyutu için I ${ }^{2}$ değerinin $\% 36,345$ olduğu görülmektedir. Bunun yanında $p$ değeri $(.001) p=.05$ 'ten küçüktür. Tüm bu değerler $(Q=25,135, p<.05$, $\left.I^{2}=36,345\right)$ etki büyüklükleri arasında düşük düzeyde de olsa heterojen bir dağılım olduğunu ve etki büyüklüklerinin yorumlanmasında rastgele etkiler modelinin kullanılması gerektiğini göstermektedir.

Medeni durum değişkeninin örgütsel bağlılığın duygusal bağlıık boyutunda araştırmaya dahil edilen 17 çalışmanın ortalama etki büyüklüğü hesaplandığında, \% 95'lik güven aralığının -0,198 alt sınırı ile -0,050 üst sınırında ortalama etki büyüklüğü $E S=-0,124$ olarak medeni duruma göre örgütsel bağılığın duygusal bağlıık boyutunda bekar öğretmenlerin evli öğretmenlere göre daha fazla duygusal bağlılık yaşadığı görülmüştür. Thalheimer ve Cook (2002) tarafindan belirtilen düzey sınıflamasına göre, etki büyüklüğü değerinin önemsiz bir etkiye sahip olduğu belirlenmiştir.

Medeni durum değişkenine göre hesaplanan etki değerlerine araştırma türü ve yılı değişkenlerinin ara değişken etkisi de incelenmiştir. Araştırma türü ara değişkenleri tez $(n=16)$ ve makale $(n=3)$ olarak iki gruba ayrılmıştır. Araştrrma türü gruplarına ait etki büyüklükleri tez türündeki çalışmalar için -0.140, makaleler türündeki çalışmalar için -0.209 olarak hesaplanmıştr. Araştırma türü ara değişkeni için çalışmalar arası varyans istatistiksel olarak anlamlı değildir. Çaıışmaların makale ya da tez olması medeni durum değişkenine göre öğretmenlerin örgütsel bağılığın duygusal bağlılık boyutuna ilişkin etki büyüklüğünü değiştirmektedir. 
Yayın yılı ara değişkenleri 2009 (n=2), 2010 (n=2), 2012 (n=4), 2014 (n=5), 2017 (n=2) olarak beş gruba ayrılmıştır. Ancak yayın sayısının azlığı nedeniyle 2013 ve 2016 yılında yapılan iki araştırma değerlendirmeye alınmamıştır. Yayın yılı kategorilerine ait etki büyüklükleri 2009 yılı için -0.90, 2010 yılı için -0.180, 2012 yılı için -0.210, 2014 yılı için -0.221, 2017 yılı için -0.038 olarak hesaplanmıştır. Yayın yılı ara değişkeni için çalışmalar arası varyans istatistiksel olarak anlamIı değildir. Çalışmaların farklı yıllarda yapılmıs olması medeni durum değişkenine göre öğretmenlerin örgütsel bağıı̆̆ın duygusal bağ|ılık boyutuna ilişkin etki büyüklüğünü değiştirmemektedir.

\begin{tabular}{|c|c|c|c|c|c|c|c|c|c|c|c|c|c|}
\hline \multirow[t]{2}{*}{ Model } & \multirow[t]{2}{*}{ Study name } & \multicolumn{7}{|c|}{ Statistics for each study } & \multicolumn{5}{|c|}{ Hedges's $\mathrm{g}$ and $95 \% \mathrm{Cl}$} \\
\hline & & Hedges's g & $\begin{array}{l}\text { Standard } \\
\text { error }\end{array}$ & Variance & Lower limit & Upper limit & ZValue & p.Value & $-2,00$ & $-1,00$ & 0,00 & 1,00 & 2,00 \\
\hline & Akgiil 2014 & $.0,118$ & 0,179 & 0,032 & $-0,469$ & 0,233 & $.0,660$ & 0,510 & & & 7 & & \\
\hline & Akyol Atan Gökmen 2012 & $.0,331$ & 0,129 & 0,017 & $.0,583$ & $.0,079$ & $\cdot 2,578$ & 0,010 & & & - & & \\
\hline & Aslan 2017 & $.0,042$ & 0,090 & 0,008 & $.0,220$ & 0,135 & $\cdot 0,470$ & 0,638 & & & $\rightarrow$ & & \\
\hline & Aydoğan 2010 & $.0,155$ & 0,165 & 0,027 & $-0,478$ & 0.167 & $.0,944$ & 0,345 & & & + & & \\
\hline & Coşkun 2012 & 0,059 & 0,116 & 0,014 & $.0,170$ & 0,287 & 0,504 & 0,614 & & & - & & \\
\hline & Gören 2012 & $.0,345$ & 0,129 & 0,017 & $.0,597$ & $.0,093$ & $-2,682$ & 0,007 & & & - & & \\
\hline & Kaygısız 2012 & .0 .225 & 0,160 & 0,026 & $.0,539$ & 0,088 & $-1,410$ & 0,159 & & & + & & \\
\hline & Korkmaz H. 2014 & $.0,156$ & 0,117 & 0,014 & $-0,384$ & 0,073 & $-1,335$ & 0,182 & & &, & & \\
\hline & Kormaz 0. 2014 & $.0,006$ & 0,106 & 0,011 & $-0,215$ & 0,202 & $-0,057$ & 0,955 & & & 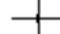 & & \\
\hline & Kurşunoğlu Bakay Tanrioğen 2010 & $.0,206$ & 0,153 & 0,023 & $.0,505$ & 0,093 & $-1,352$ & 0,176 & & & 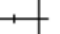 & & \\
\hline & Menep 2009 & $.0,090$ & 0,098 & 0,010 & $.0,282$ & 0,103 & $\cdot 0,915$ & 0,360 & & & $\longrightarrow$ & & \\
\hline & Selçuklu 2013 & 0,064 & 0,124 & 0,015 & $-0,180$ & 0,308 & 0.516 & 0,606 & & & 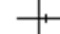 & & \\
\hline & Sönmez 206 & $.0,092$ & 0,151 & 0,023 & $-0,387$ & 0,203 & $.0,610$ & 0,542 & & & $\longrightarrow$ & & \\
\hline & Uştu 2014 & $.0,070$ & 0,078 & 0,006 & $\cdot 0,222$ & 0,082 & $.0,902$ & 0,367 & & & 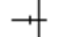 & & \\
\hline & Uysal 2014 & $.0,755$ & 0,192 & 0,037 & $-1,131$ & $-0,380$ & $-3,942$ & 0,000 & & & & & \\
\hline & Vurdu 2017 & $.0,035$ & 0,115 & 0,013 & $-0,259$ & 0,190 & $\cdot 0,302$ & 0,763 & & & & & \\
\hline & Yalçin 2009 & $.0,091$ & 0,140 & 0,020 & $-0,365$ & 0,183 & $\cdot 0,650$ & 0,516 & & &, & & \\
\hline Fixed & & $.0,111$ & 0,029 & 0,001 & $-0,169$ & $.0,054$ & $\cdot 3,801$ & 0,000 & & & + & & \\
\hline Random & & $.0,124$ & 0,038 & 0,001 & $-0,198$ & $.0,050$ & $\cdot 3,268$ & 0,001 & & & + & & \\
\hline
\end{tabular}

Şekil 4.Medeni durumun, öğretmenlerin örgütsel bağlılığının duygusal bağlılık boyutu üzerindeki etkisini gösteren orman grafiği

Medeni durumun, öğretmenlerin örgütsel bağlıı̆̆ının devam bağıılığı boyutu üzerindeki etkisini ortaya çıkaran meta-analiz sonuçları

Homojenlik testi sonucunda medeni durum değişkeni için örgütsel bağılığın devam bağlılığı boyutu için Q istatistiksel değeri 10,965 olarak hesaplanmıştır. Ki-kare tablosundan \%95 anlamlılık düzeyinde 15 serbestlik derecesi ile kritik değer 24,996 olarak kabul edilmektedir. Bu araşttrmada hesaplanan $Q$ istatistiksel değeri $(10,965)$, kritik değer olan 24,996'ten küçüktür. Medeni durum değişkeni için örgütsel bağlılı̆ın devam bağlılı̆ı boyutu için I ${ }^{2}$ değerinin $\% 0,00$ olduğu görülmektedir. Bunun yanında $p$ değeri (.022) $p=.05^{\prime}$ ten küçüktür. Tüm bu değerler $\left(Q=27,587, p<.05, I^{2}=0,000\right)$ homojenliğe işaret etmektedir. Etki büyüklüklerinin yorumlanmasında sabit etkiler modelinin kullanılması uygundur.

Medeni durum değişkeninin örgütsel bağ|ıığın devam bağlılığı boyutunda araştrmaya dahil edilen 16 çalışmanın ortalama etki büyüklüğü hesaplandığında, \% 95'lik güven aralığının -0,127 alt sınırı ile -0,010 üst sınırında ortalama etki büyüklüğü $\mathrm{ES}=-0,069$ olarak medeni duruma göre örgütsel bağlılığın devam bağılığı boyutunda bekar öğretmenlerin evli öğretmenlere göre daha fazla devam bağlılığı yaşadığı görülmüştür. Thalheimer ve Cook (2002) tarafindan belirtilen düzey sınıflamasına göre, etki büyüklüğü değerinin önemsiz bir etkiye sahip olduğu belirlenmiştir.

\begin{tabular}{|c|c|c|c|c|c|c|c|c|c|c|c|c|c|}
\hline \multirow[t]{2}{*}{ Model } & \multirow[t]{2}{*}{ Study name } & \multicolumn{7}{|c|}{ Statistics for each study } & \multicolumn{5}{|c|}{ Hedges's $\mathrm{g}$ and $95 \% \mathrm{Cl}$} \\
\hline & & Hedges's g & $\begin{array}{l}\text { Standard } \\
\text { error }\end{array}$ & Variance & Lower limit & Upper limit & ZValue & $\mathrm{p}$-Value & $-1,00$ & $-0,50$ & 0.00 & 0,50 & 1.00 \\
\hline & Akguil 2014 & $.0,005$ & 0,179 & 0,032 & $.0,355$ & 0.346 & $-0,027$ & 0.978 & & & & & \\
\hline & Akyol Atan Gökmen 2012 & $.0,049$ & 0,128 & 0,016 & $.0,299$ & 0,202 & $.0,380$ & 0.704 & & & & & \\
\hline & Aslan 2017 & $\cdot 0,170$ & 0,091 & 0,008 & $.0,347$ & 0,007 & $-1,877$ & 0,060 & & & & & \\
\hline & Aydoğan 2010 & $\cdot 0,238$ & 0,165 & 0,027 & $.0,562$ & 0,085 & $-1,446$ & 0,148 & & & - & & \\
\hline & Coskun 2012 & 0.042 & 0,116 & 0,014 & $.0,186$ & 0.270 & 0,363 & 0.717 & & & & & \\
\hline & Gören 2012 & $\cdot 0,092$ & 0,128 & 0,016 & $.0,344$ & 0,159 & $\cdot 0,720$ & 0,472 & & & & & \\
\hline & Kaygısız 2012 & $.0,104$ & 0,160 & 0,026 & $.0,417$ & 0,209 & $.0,652$ & 0.515 & & & & & \\
\hline & Korkmaz H. 2014 & $.0,007$ & 0,116 & 0,014 & .0 .235 & 0,222 & $.0,057$ & 0.955 & & & & & \\
\hline & Kormaz 0. 2014 & $-0,008$ & 0,106 & 0,011 & $.0,217$ & 0,201 & $.0,075$ & 0,940 & & & & & \\
\hline & Kurşunoğlu Bakay Tanniöğen 2010 & $.0,203$ & 0,153 & 0,023 & $.0,501$ & 0,096 & $-1,328$ & 0,184 & & & - & & \\
\hline & Menep 2009 & $-0,059$ & 0,098 & 0,010 & .0 .251 & 0,134 & $.0,600$ & 0.549 & & & 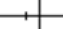 & & \\
\hline & Selçuklu 2013 & 0,250 & 0,125 & 0,016 & 0,005 & 0,494 & 1,999 & 0,046 & & & & & \\
\hline & Sönmez 206 & $.0,203$ & 0,151 & 0,023 & $.0,499$ & 0,092 & $-1,348$ & 0,178 & & & & & \\
\hline & Uştu 2014 & $.0,059$ & 0.078 & 0,006 & $\cdot 0,211$ & 0,094 & $.0,754$ & 0.451 & & & + & & \\
\hline & Uysal 2014 & $\cdot 0,357$ & 0,190 & 0,036 & $.0,730$ & 0.016 & $-1,878$ & 0,060 & & & & & \\
\hline & Vurdu 2017 & $.0,112$ & 0,115 & 0,013 & $.0,337$ & 0,113 & $.0,979$ & 0,327 & & & 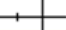 & & \\
\hline Fixed & & $\cdot 0,069$ & 0,030 & 0,001 & $\cdot 0,127$ & $.0,010$ & $\cdot 2,287$ & 0,022 & & & + & & \\
\hline Random & & $.0,069$ & 0,030 & 0,001 & $.0,127$ & .0 .010 & $.2,287$ & 0,022 & & & + & & \\
\hline
\end{tabular}

Şekil 5.Medeni durumun, öğretmenlerin örgütsel bağlılığının devam bağlılığı boyutu üzerindeki etkisini gösteren orman grafiği 
Medeni durumun, öğretmenlerin örgütsel bağlılı̆ının normatif bağlılık boyutu üzerindeki etkisini ortaya çıkaran meta-analiz sonuçları

Homojenlik testi sonucunda medeni durum değişkeni için örgütsel bağııı̆ın normatif bağılık boyutu için $Q$ istatistiksel değeri 14,593 olarak hesaplanmıştr. Ki-kare tablosundan \%95 anlamlılık düzeyinde 16 serbestlik derecesi ile kritik değer 26,296 olarak kabul edilmektedir. Bu araştırmada hesaplanan $Q$ istatistiksel değeri $(14,593)$, kritik değer olan 24,996 'ten küçüktür. Medeni durum değişkeni için örgütsel bağlılı̆ın devam bağlılı̆ı boyutu için I ${ }^{2}$ değerinin $\% 0,00$ olduğu görülmektedir. Bunun yanında $p$ değeri $(.000) p=.05^{\prime}$ ten küçüktür. Tüm bu değerler $\left(Q=14,593, p<.05, I^{2}=0,000\right)$ homojenliğe işaret etmektedir. Etki büyüklüklerinin yorumlanmasında sabit etkiler modelinin kullanılması uygundur.

Medeni durum değişkeninin örgütsel bağlılığın normatif bağlılık boyutunda araştırmaya dahil edilen 17 çalışmanın ortalama etki büyüklüğü hesaplandığında, \% 95'lik güven aralığının -0,167 alt sınırı ile -0,052 üst sınırında ortalama etki büyüklüğü $E S=-0,109$ olarak medeni duruma göre örgütsel bağılığın normatif bağlılık boyutunda bekar öğretmenlerin evli öğretmenlere göre daha fazla normatif bağılıı yaşadığı görülmüştür. Thalheimer ve Cook (2002) tarafindan belirtilen düzey sınıflamasına göre, etki büyüklüğü değerinin önemsiz bir etkiye sahip olduğu belirlenmiştir.

\begin{tabular}{|c|c|c|c|c|c|c|c|c|c|c|c|c|c|}
\hline \multirow[t]{2}{*}{ Model } & \multirow[t]{2}{*}{ Study name } & \multicolumn{7}{|c|}{ Statistics for each study } & \multicolumn{5}{|c|}{ Hedges's $\mathrm{g}$ and $95 \% \mathrm{Cl}$} \\
\hline & & Hedges's $\mathrm{g}$ & $\begin{array}{l}\text { Standard } \\
\text { error }\end{array}$ & Variance & Lower limit & Upper limit & Z-Value & p.Value & $-1,00$ & $\cdot 0,50$ & 0,00 & 0,50 & 1,00 \\
\hline & A.kguil 2014 & $\cdot 0,104$ & 0,179 & 0,032 & $\cdot 0,455$ & 0,246 & $.0,583$ & 0,560 & & & & & \\
\hline & Akyol Atan Gökmen 2012 & $.0,222$ & 0,128 & 0,016 & $\cdot 0,473$ & 0,030 & $\cdot 1,729$ & 0,084 & & & & & \\
\hline & Aslan 2017 & $.0,095$ & 0,090 & 0,008 & $\cdot 0,273$ & 0,082 & $-1,055$ & 0,292 & & & & & \\
\hline & Aydoğan 2010 & $-0,130$ & 0,165 & 0,027 & $\cdot 0,452$ & 0,193 & $-0,788$ & 0,431 & & & & & \\
\hline & Coşkun 2012 & 0,153 & 0,117 & 0,014 & $-0,076$ & 0,381 & 1,312 & 0,189 & & & & & \\
\hline & Gören 2012 & $.0,087$ & 0,128 & 0,016 & $-0,339$ & 0.164 & $.0,682$ & 0.495 & & & & & \\
\hline & Kaygııı 2012 & $.0,036$ & 0,160 & 0,026 & $\cdot 0,349$ & 0,277 & $\cdot 0,226$ & 0,821 & & & & & \\
\hline & Korkmaz H. 2014 & $.0,095$ & 0,117 & 0,014 & $\cdot 0,324$ & 0,133 & $.0,818$ & 0,414 & & & & & \\
\hline & Kormaz 0. 2014 & $.0,086$ & 0,106 & 0,011 & $\cdot 0,295$ & 0,122 & $.0,811$ & 0,418 & & & & & \\
\hline & Kurşunoğlu Bakay Tanrioğen 2010 & $\cdot 0,364$ & 0,153 & 0,023 & $\cdot 0,663$ & $.0,064$ & $\cdot 2,377$ & 0,017 & & & & & \\
\hline & Menep 2009 & $-0,118$ & 0,098 & 0,010 & $\cdot 0,311$ & 0,074 & $-1,205$ & 0,228 & & & & & \\
\hline & Selçuklu 2013 & 0,055 & 0,124 & 0,015 & $\cdot 0,189$ & 0,298 & 0,440 & 0,660 & & & & & \\
\hline & Sönmez 206 & $-0,202$ & 0,151 & 0,023 & $-0,498$ & 0,094 & $-1,340$ & 0,180 & & & & & \\
\hline & Uş̧u 2014 & $\cdot 0,148$ & 0,078 & 0,006 & $\cdot 0,300$ & 0,004 & $-1,904$ & 0.057 & & & & & \\
\hline & Uysal 2014 & $\cdot 0,128$ & 0,190 & 0,036 & $.0,500$ & 0,244 & $\cdot 0,675$ & 0,500 & & & & & \\
\hline & Vurdu 2017 & $.0,298$ & 0,115 & 0,013 & $\cdot 0,524$ & $.0,072$ & $.2,585$ & 0,010 & & & & & \\
\hline & Yalçin 2009 & $.0,001$ & 0,140 & 0,020 & $\cdot 0,275$ & 0,272 & $.0,010$ & 0,992 & & & & & \\
\hline Fixed & & 0,109 & 0,029 & 0,001 & $\cdot 0,167$ & $\cdot 0,052$ & $\cdot 3,727$ & 0,000 & & & + & & \\
\hline Random & & $\cdot 0,109$ & 0,029 & 0,001 & $\cdot 0,167$ & $-0,052$ & $-3,727$ & 0,000 & & & + & & \\
\hline
\end{tabular}

Şekil 6.Medeni durumun, öğretmenlerin örgütsel bağlılığının normatif bağlılık boyutu üzerindeki etkisini gösteren orman grafiği

\section{Üçüncü alt probleme ilişkin bulgular}

Branşın, öğretmenlerin örgütsel bağ|ılığının duygusal bağ|ılık, devam bağlılığı ve normatif bağlııkları üzerindeki etkisini ortaya çıkaran meta-analiz sonuçları Tablo 4'te sunulmuştur.

Tablo 4. Etki modellerine göre meta-analiz çalışması sonuçlarının karşılaştırılması (Branş)

\begin{tabular}{|c|c|c|c|c|c|c|c|c|c|c|}
\hline \multirow{2}{*}{$\begin{array}{l}\text { Örgütsel } \\
\text { Bağlılık }\end{array}$} & \multirow{2}{*}{ Model } & \multirow{2}{*}{ df } & \multirow{2}{*}{ z } & \multirow{2}{*}{$\mathrm{p}$} & \multirow{2}{*}{$1^{2}$} & \multirow{2}{*}{ Q } & \multirow{2}{*}{$\begin{array}{c}\text { Ki Kare tablo } \\
\text { değeri }\end{array}$} & \multirow{2}{*}{ ES } & \multicolumn{2}{|c|}{ Güven Aralığı } \\
\hline & & & & & & & & & Alt Sınır & Üst Sınır \\
\hline Duygusal & Sabit Etkiler Modeli & 6 & $-4,386$ & 0,000 & & 17,035 & 12,592 & $-0,173$ & $-0,251$ & $-0,096$ \\
\hline Bağlılık & Rastgele Etkiler Modeli & 6 & $-2,839$ & 0,005 & 64,779 & 17,035 & 12,592 & $-0,197$ & $-0,333$ & $-0,061$ \\
\hline Devam & Sabit Etkiler Modeli & 6 & $-1,859$ & 0,063 & & 7,276 & 12,592 & $-0,073$ & $-0,151$ & $-0,004$ \\
\hline Bağ|ılığı & Rastgele Etkiler Modeli & 6 & $-1,822$ & 0,068 & 17,533 & 7,276 & 12,592 & $-0,081$ & $-0,168$ & $-0,006$ \\
\hline Normatif & Sabit Etkiler Modeli & 6 & $-4,748$ & 0,000 & & 20,623 & 12,592 & $-0,188$ & $-0,266$ & $-0,110$ \\
\hline Bağlılık & Rastgele Etkiler Modeli & 6 & $-2,653$ & 0,008 & 70,906 & 20,623 & 12,592 & $-0,202$ & $-0,352$ & $-0,053$ \\
\hline
\end{tabular}

Branşın, öğretmenlerin örgütsel bağlıı̆ıının duygusal bağıılık boyutu üzerindeki etkisini ortaya çıkaran meta-analiz sonuçları

Homojenlik testi sonucunda branş değişkeni için örgütsel bağ|ı̆ı̆ın duygusal bağlılık boyutu için Q istatistiksel değeri 17,035 olarak hesaplanmıştır. Ki-kare tablosundan \%95 anlamlılık düzeyinde 6 serbestlik derecesi ile kritik değer 12,592 olarak kabul edilmektedir. Bu araştrrmada hesaplanan Q istatistiksel değeri (17,035), kritik değer olan 12,592'den büyüktür. Branş değişkeni için örgütsel bağlılığın duygusal bağlılık boyutu için I ${ }^{2}$ değerinin $\% 64,779$ olduğu görülmektedir. Bunun yanında $p$ değeri $(.005) p=.05^{\prime}$ ten küçüktür. Tüm bu değerler $\left(Q=17,035, p<.05, I^{2}=64,779\right)$ etki büyüklükleri arasında heterojen bir dağılım olduğunu ve etki büyüklüklerinin yorumlanmasında rastgele etkiler modelinin kullanıl- 
ması gerektiğini göstermektedir.

Branş değişkeninin örgütsel bağlılığın duygusal bağlılık boyutunda araştırmaya dahil edilen 7 çalışmanın ortalama etki büyüklüğü hesaplandığında, \% 95'lik güven aralığının -0,333 alt sınırı ile -0,061 üst sınırında ortalama etki büyüklüğü ES= -0,197 olarak branşa göre örgütsel bağlılığın duygusal bağlılık boyutunda sınıf öğretmenlerinin branş öğretmenlerine göre daha fazla duygusal bağlılık yaşadığı görülmüştür. Thalheimer ve Cook (2002) tarafindan belirtilen düzey sınıflamasına göre, etki büyüklüğü değerinin önemsiz bir etkiye sahip olduğu belirlenmiştir.

Branş değişkenine göre hesaplanan etki değerlerine araştırma türü ara değişken olarak alınmazken araştırma yılı ara değişken etkisi de incelenmiştir. Araştırma türünde makale türü sayısının azlığı buna neden olarak gösterilebilir. Yayın yılı ara değişkenleri 2009 (n=2), 2010 (n=2), 2012 (n=2)olarak üç gruba ayrılmıştır. Ancak yayın sayısının azlığı nedeniyle 2017 yılında yapılan bir araştırma değerlendirmeye alınmamıştır. Yayın yılı kategorilerine ait etki büyüklükleri 2009 yılı için -0.306, 2010 yılı için -0.102, 2012 yılı için -0.208 olarak hesaplanmıştır. Yayın yılı ara değişkeni için çalışmalar arası varyans istatistiksel olarak anlamlı değildir. Çalışmaların farklı yıllarda yapılmış olması branş değişkenine göre öğretmenlerin örgütsel bağlılığın duygusal bağ|ılık boyutuna ilişkin etki büyüklüğünü değiştirmemektedir.

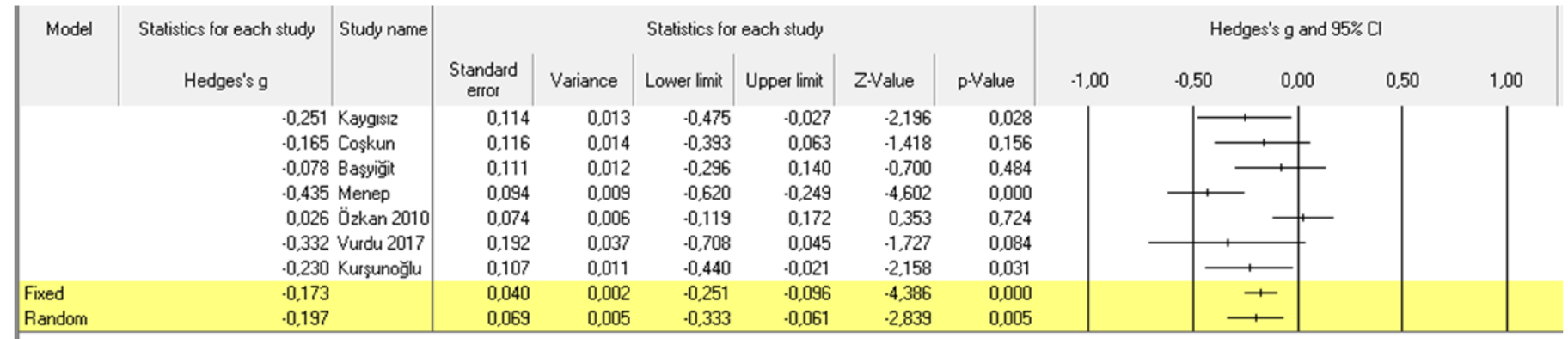

Şekil 7.Branşın, öğretmenlerin örgütsel bağlılığının duygusal bağlılık boyutu üzerindeki etkisini gösteren orman grafiği

Branşın, öğretmenlerin örgütsel bağlılığının devam bağlılığı boyutu üzerindeki etkisini ortaya çıkaran meta-analiz sonuçları

Homojenlik testi sonucunda branş değişkeni için örgütsel bağıı̆ı̆ın devam bağlılığı boyutu için Q istatistiksel değeri 7,276 olarak hesaplanmıştır. Ki-kare tablosundan \%95 anlamlılık düzeyinde 6 serbestlik derecesi ile kritik değer 12,592 olarak kabul edilmektedir. Bu araştırmada hesaplanan Q istatistiksel değeri (7,276), kritik değer olan 12,592'den küçüktür. Branş değişkeni için örgütsel bağlılığın devam bağıılığı boyutu için I ${ }^{2}$ değerinin \%17,533 olduğu görülmektedir. Bunun yanında $p$ değeri (.068) $p=.05^{\prime}$ ten büyüktür. Tüm bu değerler $\left(Q=7,276, p>.05, I^{2}=17,533\right)$ homojenliğe işaret etmektedir. Etki büyüklüklerinin yorumlanmasında sabit etkiler modelinin kullanılması uygundur.

Branş değişkeninin örgütsel bağlılığın devam bağlılığı boyutunda araştırmaya dahil edilen 7 çalışmanın ortalama etki büyüklüğü hesaplandığında, \% 95'lik güven aralığının -0,151 alt sınırı ile -0,004 üst sınırında ortalama etki büyüklüğü $E S=-0,073$ olarak branşa göre örgütsel bağ|ılığın devam bağ|ılı̆̆ boyutunda sınıf öğretmenlerinin branş öğretmenlerine göre daha fazla devam bağlılığı yaşadığı görülmüştür. Thalheimer ve Cook (2002) tarafindan belirtilen düzey sınıflamasına göre, etki büyüklüğü değerinin önemsiz bir etkiye sahip olduğu belirlenmiştir.

\begin{tabular}{|c|c|c|c|c|c|c|c|c|c|c|c|c|c|}
\hline \multirow[t]{2}{*}{ Model } & \multirow[t]{2}{*}{ Study name } & \multicolumn{7}{|c|}{ Statistics for each study } & \multicolumn{5}{|c|}{ Hedges's $\mathrm{g}$ and $95 \% \mathrm{Cl}$} \\
\hline & & Hedges's g & $\begin{array}{l}\text { Standard } \\
\text { error }\end{array}$ & Variance & Lower limit & Upper limit & Z:Value & p.Value & $-1,00$ & $-0,50$ & 0,00 & 0,50 & 1,00 \\
\hline & Kaygısı 2012 & $-0,164$ & 0,114 & 0,013 & $\cdot 0,388$ & 0,059 & $-1,443$ & 0,149 & & & & & \\
\hline & Coşkun 2012 & $\cdot 0,147$ & 0,116 & 0,014 & $-0,375$ & 0,082 & $-1,258$ & 0,208 & & & - & & \\
\hline & Basyiğt 2009 & $-0,080$ & 0,111 & 0,012 & $.0,299$ & 0,138 & $-0,721$ & 0,471 & & & + & & \\
\hline & Menep 2009 & $\cdot 0,001$ & 0,093 & 0,009 & $.0,184$ & 0,182 & $.0,010$ & 0,992 & & & - & & \\
\hline & Özkan 2010 & 0,050 & 0,074 & 0,006 & $.0,096$ & 0,195 & 0.670 & 0,503 & & & - & & \\
\hline & Vurdu 2017 & $\cdot 0,158$ & 0.192 & 0,037 & $.0,534$ & 0,218 & $\cdot 0,825$ & 0,410 & & & & & \\
\hline & Kurşunoğlu Bakay Tanriöğen 2010 & $-0,249$ & 0.107 & 0.011 & $-0,458$ & $.0,039$ & $-2,328$ & 0,020 & & & - & & \\
\hline Fixed & & $.0,073$ & 0,039 & 0,002 & $.0,151$ & 0,004 & $-1,859$ & 0,063 & & & + & & \\
\hline Random & & $.0,081$ & 0,044 & 0,002 & $.0,168$ & 0,006 & $-1,822$ & 0,068 & & & $\rightarrow$ & & \\
\hline
\end{tabular}

Şekil 8.Branşın, öğretmenlerin örgütsel bağlılığının devam bağlılığı boyutu üzerindeki etkisini gösteren orman grafiği 


\section{Branşın, öğretmenlerin örgütsel bağlılığının normatif bağlılık boyutu üzerindeki etkisini ortaya çıkaran meta-ana- liz sonuçları}

Homojenlik testi sonuçları kritik değerden düşük çıktğı için sabit etkiler modeli değerlendirilmiştir. Homojenlik testi sonucunda branş değişkeni için örgütsel bağlılığın normatif bağlılık boyutu için $Q$ istatistiksel değeri 20,623 olarak hesaplanmıştır. Ki-kare tablosundan \%95 anlamlılık düzeyinde 6 serbestlik derecesi ile kritik değer 12,592 olarak kabul edilmektedir. Bu araşttrmada hesaplanan Q istatistiksel değeri (20,623), kritik değer olan 12,592'den büyüktür. Branş değişkeni için örgütsel bağlılığın normatif bağılıık boyutu için I ${ }^{2}$ değerinin $\% 70,906$ olduğu görülmektedir. Bunun yanında $p$ değeri (.023) $p=.05^{\prime}$ ten küçüktür. Tüm bu değerler $\left(Q=20,623, p<.05, I^{2}=70,906\right)$ etki büyüklükleri arasında heterojen bir dağılım olduğunu ve etki büyüklüklerinin yorumlanmasında rastgele etkiler modelinin kullanılması gerektiğini göstermektedir.

Branş değişkeninin örgütsel bağlılı̆ın normatif bağlıık boyutunda araştırmaya dahil edilen 7 çalışmanın ortalama etki büyüklüğü hesaplandığında, \% 95'lik güven aralığının -0,352 alt sınırı ile -0,053 üst sınııında ortalama etki büyüklüğü ES= -0,202 olarak branşa göre örgütsel bağ|ılığın devam bağlılığı boyutunda sınıf öğretmenlerinin branş öğretmenlerine göre daha fazla normatif bağılık yaşadığı görülmüştür. Thalheimer ve Cook (2002) tarafindan belirtilen düzey sınıflamasına göre, etki büyüklüğü değerinin önemsiz bir etkiye sahip olduğu belirlenmiştir.

Branş değişkenine göre hesaplanan etki değerlerine araştırma türü ara değişken olarak alınmazken araştırma yılı ara değişken etkisi de incelenmiştir. Araştırma türünde makale türü sayısının azlığı buna neden olarak gösterilebilir. Yayın yılı ara değişkenleri 2009 (n=2), $2010(n=2), 2012(n=2)$ olarak üç gruba ayrılmıştı. Ancak yayın sayısının azlığı nedeniyle 2017 yılında yapılan bir araştırma değerlendirmeye alınmamıştır. Yayın yılı kategorilerine ait etki büyüklükleri 2009 yılı için $-0.267,2010$ yılı için $-0.160,2012$ yılı için -0.227 olarak hesaplanmıştır. Yayın yılı ara değişkeni için çalışmalar arası varyans istatistiksel olarak anlamlı değildir. Çalışmaların farklı yıllarda yapılmış olması branş değişkenine göre öğretmenlerin örgütsel bağ|ılığın normatif bağ|ılık boyutuna ilişkin etki büyüklüğünü değiştirmemektedir.

\begin{tabular}{|c|c|c|c|c|c|c|c|c|c|c|c|c|c|}
\hline \multirow[t]{2}{*}{ Model } & \multirow[t]{2}{*}{ Study name } & \multicolumn{7}{|c|}{ Statistics for each study } & \multicolumn{5}{|c|}{ Hedges's $\mathrm{g}$ and $95 \% \mathrm{Cl}$} \\
\hline & & Hedges's g & $\begin{array}{l}\text { Standard } \\
\text { error }\end{array}$ & Variance & Lower limit & Upper limit & ZVValue & p.Value & $-1,00$ & $\cdot 0,50$ & 0,00 & 0,50 & 1,00 \\
\hline & Kaygısı 2012 & $.0,236$ & 0,114 & 0,013 & $.0,460$ & $.0,012$ & $\cdot 2,068$ & 0,039 & & & & & \\
\hline & Coşkun 2012 & $.0,219$ & 0,117 & 0,014 & $-0,447$ & 0,010 & $-1,874$ & 0,061 & & & & & \\
\hline & Bassyiğit 2009 & $.0,065$ & 0,111 & 0.012 & $.0,283$ & 0,153 & $\cdot 0,584$ & 0,559 & & & & & \\
\hline & Menep 2009 & $.0,469$ & 0,095 & 0,009 & $.0,654$ & .0 .283 & $-4,957$ & 0,000 & & & & & \\
\hline & Özkan 2010 & 0,022 & 0,074 & 0,006 & $.0,124$ & 0,167 & 0,290 & 0,772 & & & & & \\
\hline & Vurdu 2017 & $.0,081$ & 0,192 & 0,037 & $-0,457$ & 0,295 & $\cdot 0,423$ & 0,672 & & & & & \\
\hline & Kurşunoğlu Bakay Tanniöğen 2010 & $.0,342$ & 0,107 & 0,011 & $.0,552$ & $.0,132$ & $.3,194$ & 0,001 & & & & & \\
\hline Fixed & & $.0,188$ & 0,040 & 0,002 & $-0,266$ & $.0,110$ & $-4,748$ & 0,000 & & & & & \\
\hline Random & & $.0,202$ & 0,076 & 0,006 & $-0,352$ & $.0,053$ & $-2,653$ & 0,008 & & & & & \\
\hline
\end{tabular}

Şekil 9. Branşın, öğretmenlerin örgütsel bağlılığının normatif bağlılık boyutu üzerindeki etkisini gösteren orman grafiği

\section{Sonuçlar}

Cinsiyet, medeni durum ve branş değişkenlerinin öğretmenlerin örgütsel bağ|ılıkları üzerindeki etkisini ortaya koymayı amaçlayan bu meta analizde dahil etme kriterlerini karşılayan 23 çalışma incelenmiştir. Araşttrma sonuçları;cinsiyet, medeni durum ve branş değişkenleri için örgütsel bağlılı̆ın tüm alt boyutlarında ortalama etki büyüklüğü değerinin, Thalheimer ve Cook (2002) sınıflandırmasına göre önemsiz düzeyde olduğunu göstermektedir. Her bir değişken için örgütsel bağ|ıIı̆ın tüm alt boyutları için elde edilen sonuçlar şu şekildedir:

Araştırmada, cinsiyet değişkeni açısından örgütsel bağılıı̆ın alt boyutlarında sabit ve rastgele etkiler modeline göre yapılan meta-analiz doğrultusunda ortalama etki büyüklüğü duygusal bağlıık alt boyutu için -0,114, devam bağlılığı alt boyutu $-0,072$, normatif bağlılık alt boyutu için $-0,153$ olarak bulunmuştur. Tüm alt boyutlar için ortalama etki büyüklüğü değerinin, Thalheimer ve Cook (2002) sınıflandırmasına göre önemsiz düzeyde olduğu görülmektedir. Bu bulgular erkeklerin kadınlara göre örgütlerine daha fazla bağlandıkları şeklinde yorumlanabilir. Alan yazın incelendiğinde bazı meta-analiz çalışmalarının da aynı sonucu ortaya koyduğu söylenebilir (Aydın, Sarıer ve Uysal, 2011; Aven, Parker ve McEnvoy, 1993). Meta analize dâhil edilen ve cinsiyet değişkeni için örgütsel bağlılı̆ın tüm alt boyutlarına göre fark bulunan araştırmaların üçü dışında (Menep; 2009; Yörük ve Sağban, 2012; Sönmez, 2016) tümünde (Akgül, 2014; Aslan, 2017; Aydoğan, 2010; Başyiğit, 2009; Coşkun, 2012; Gören, 2012; Karaköse, 2012; Kılıçoğlu, 2010: Korkmaz, 2014, Kurşunoğlu vd., 2010; Özkan, 2010; Serdaroğlu, 2013; Uştu, 2014; Uysal, 2014; Vurdu, 2017; Yalçın, 2009) erkek öğretmenlerde kadın öğretmenlere göre daha fazla duygusal bağlıık olduğu bulgusuna ulaşılmıştır. Kadınların kimliklerinin ve tatminlerinin odak noktasında aile rolleri vardır. Bu bağlamda iş rolleri onlar için annelik rollerinden geri plandadır. 
Fakat erkekler için bu durumun tersi söz konusudur. Kadınlarda işe devamsızlık ve işi bırakma olgularına daha çok rastlanılmaktadır(Aven ve ark., 1993). Bu çalışmada analiz sonucu ortaya çıkan önemli ara değişkenler de dikkate alınmıştır. Analiz sonucunda araşttrma türü ve yılı ara değiş̧kenlerinin cinsiyet değişkeni açısından öğretmenlerin örgütsel bağıı̆ğı alt boyutlarından duygusal bağıııklarını ve normatif bağlılıklarını etkilemediği belirlenmiştir.

Araştırmada, medeni durum değişkeni açısından örgütsel bağıı̆ı̆ın alt boyutlarında sabit ve rastgele etkiler modeline göre yapılan meta-analiz doğrultusunda ortalama etki büyüklüğü duygusal bağlıık alt boyutu için -0,111, devam bağ|ıı̆̆ alt boyutu $-0,069$, normatif bağ|lıık alt boyutu için $-0,109$ olarak bulunmuştur. Tüm alt boyutlar için ortalama etki büyüklüğü değerinin, Thalheimer ve Cook (2002) sınıflandırmasına göre önemsiz düzeyde olduğu görülmektedir. Bu bulgu bekar öğretmenlerin evli öğretmenlere göre örgütlerine daha fazla bağlandıkları şeklinde yorumlanabilir. Alan yazın incelendiğinde medeni durum değişkeni açısından örgütsel bağııı̆ı inceleyen bir meta-analiz çalışmasına rastlanmamıştrr. Meta analize dâhil edilen ve medeni durum değişkeni için örgütsel bağlıı̆̆ın duygusal alt boyutuna göre fark bulunan araştırmaların ikisi dışında (Coşkun, 2012; Selçuklu, 2013) tümünde (Akgül, 2014; Akyol vd., 2012; Aslan, 2017; Aydoğan, 2010; Gören, 2012;Kaygısız, 2012; Korkmaz, 2014; Korkmaz, 2014; Kurşunoğlu, 2010; Menep, 2009; Sönmez, 2016; Uştu, 2014; Uysal, 2014; Vurdu, 2017; Yalçın, 2009) bekar öğretmenlerin evli öğretmenlere göre örgütlerine daha fazla bağıı olduğu bulgusuna ulaşılmıştır. Meta analize dâhil edilen ve medeni durum değişkeni için örgütsel bağlıı̆ın devam bağlıığı ve normatif bağlıık alt boyutlarına göre fark bulunan araştırmaların biri dışında (Coşkun, 2012) tümünde (Akgül, 2014; Akyol vd., 2012; Aslan, 2017; Aydoğan, 2010; Gören, 2012; Kaygısız, 2012; Korkmaz, 2014; Korkmaz, 2014; Kurşunoğlu, 2010; Menep, 2009; Selçuklu, 2013; Sönmez, 2016; Uştu, 2014; Uysal, 2014; Vurdu, 2017; Yalçın, 2009) bekar öğretmenlerin evli öğretmenlere göre örgütlerine daha fazla bağlı olduğu bulgusuna ulaşılmıştır. Bu çaıışmada analiz sonucu ortaya çıkan önemli ara değişkenler de dikkate alınmıştır. Analiz sonucunda araştırma türü ve yılı ara değişkenlerinin medeni durum değişkeni açısından öğretmenlerin örgütsel bağlılığı alt boyutlarından duygusal bağ|ılı̆ını etkilemediği belirlenmiştir.

Araştırmada, branş değişkeni açısından örgütsel bağlılığın alt boyutlarında sabit ve rastgele etkiler modeline göre yapılan meta-analiz doğrultusunda ortalama etki büyüklüğü duygusal bağlılık alt boyutu için -0,197, devam bağılığı alt boyutu $-0,073$, normatif bağ|lıı alt boyutu için $-0,202$ olarak bulunmuştur. Tüm alt boyutlar için ortalama etki büyüklüğü değerinin, Thalheimer ve Cook (2002) sınıflandırmasına göre önemsiz düzeyde olduğu görülmektedir. Bu bulgu sınıf öğretmenlerinin branş öğretmenlerine oranla örgütlerine daha fazla bağlandıkları şeklinde yorumlanabilir. Alan yazın incelendiğinde branş değişkeni açısından örgütsel bağlılı̆ı inceleyen bir meta-analiz çalışmasına rastlanmamıştr. Alan yazın incelendiğinde bazı meta-analiz çalışmalarının da aynı sonucu ortaya koyduğu söylenebilir (Aydın, Sarıer ve Uysal, 2011; Aven, Parker ve McEnvoy, 1993). Meta analize dâhil edilen ve branş değişkeni iç̧in örgütsel bağlılığın tüm alt boyutlarına göre fark bulunan araştırmaların biri dışında (Özkan, 2010) tümünde (Başyiğit, 2009; Coşkun, 2012; Kaygısız, 2012; Kurşunoğlu, 2010; Menep, 2009; Vurdu, 2017) sınıf öğretmenlerinin branş öğretmenlerine göre örgütlerine daha fazla bağı olduğu bulgusuna ulaşılmıştı. Bu çalışmada analiz sonucu ortaya çıkan önemli ara değişkenler de dikkate alınmıştır. Analiz sonucunda araştırma türü ve yılı ara değişkenlerinin branş değişkeni açısından öğretmenlerin örgütsel bağ|ılığının duygusal bağlııı̆ını etkilemediği belirlenmiştir.

Araştırmanın önerileri ve sınırlılıkları şu şekildedir:

Çalışmanın sınırlılıklarından biri, birincil çalışmalardan elde edilen verilerin sadece tarama çalışmalarına dayanıyor olmasıdır. Öğretmenlerin örgütsel bağlılıkları nitel araştırma yöntemleri kullanılarak derinlemesine anlaşılabilir. Ayrıca örgütsel bağ|ılık araştırmalarının büyük çoğunluğunun korelasyonel araştırmalardan meydana gelmesi de potansiyel yöntem yanlııı̆ının olabileceğini göstermektedir.

Çalışmanın sınırlııklarından bir diğeri, tüm birincil çalışmalara ulaşmanın bu araştırmada pek mümkün olmamasıdır. YÖK Tez Merkezi veri tabanında erişim izni verilmeyen çalışmalar kapsam dışında kaldı. Ayrıca Türkiye'de tam olarak akademik makalelerin indekslendiği bir veri tabanı bulunmamaktadır. Ulakbim veya diğer veri tabanlarında 2004 öncesine ait araştırmalara tam olarak yer verilmemiş olmasından sınırlı çalışmalara ulaşııldı.

Bunun yanında meta-analiz sonuçlarının yayın yanlılığından etkilendiği yukarıda belirtilmişti. Dinçer (2014) rastgele veya ciddi bir hakem değerlendirmesine tabi tutulmamış çalışmaların (bildiri, rapor vb.) analize alınması yayın yanlılığına neden olacağını vurgularken. Bazı araştırmacılar meta-analizde dosya çekmecesi probleminin olduğunu savunur. Yani sadece yayınlanmış araştırmalara güvenmek yayın yanlılığına neden olabilecektir (Rosenthal, 1979). Bu çalışmada araştırmacılar alan yazındaki bu farklı bakış açılarııın farkındadır ve sempozyum, kongre, vb. bilimsel etkinliklerde sunulan bildirilere yer vermemeyi tercih etmişlerdir. Bu bir sınırlılık olarak düşünülebilir.

Meta-analizi sadece 2009-2017 yılları arasında Türkiye'de yapılmış araştırmaların oluşturması da bir diğer sınırlılık 
olarak gösterilebilir.

Araştrrma kapsamında şu öneriler sunulmuştur:

- Yayın yılı aralığı daha geniş tutularak, yurt dışında yapılan birincil araştırmalar meta analize dâhil edilerek metaanaliz yapılabilir.

- Yapılan çalışmada cinsiyet, medeni durum, branş değişkenlerinin örgütsel bağlılığa etkisi incelenmiştir. Araştırmacılar diğer bağımsız değişkenlerin de örgütsel bağlılığa etkilerini inceleyebilirler.

- Çalışmada öğretmenlerin örgütsel bağlılığına cinsiyetin etkisinin önemsiz düzeyde olduğu ve erkek öğretmenlerin kadın öğretmenlere göre daha fazla örgütsel bağlıık yaşadığı sonucuna ulaşıımıştır. Araştırmacılar bu durumun nedenlerine ilişkin derinlemesine analiz içeren çalışmalar yapabilirler. Böylece eğitim paydaşlarına öğretmenlerin örgütsel bağlılıklarını artırmaya yönelik yapılacak çalışmalarda vizyon oluşur.

- Çalışmada öğretmenlerin örgütsel bağılıı̆ına medeni durum etkisinin önemsiz düzeyde ve bekar öğretmenlerin evli öğretmenlere göre daha fazla örgütsel bağılıık yaşadığı sonucuna ulaşılmıştır. Araştırmacılar bu durumun nedenlerine ilişkin derinlemesine analiz içeren çalışmalar yapılabilirler. Böylece eğitim paydaşlarına öğretmenlerin örgütsel bağlılıklarını artırmaya yönelik yapılacak çalışmalarda vizyon oluşur.

- Çalışmada öğretmenlerin örgütsel bağılıı̆ına branşın etkisinin önemsiz düzeyde olduğu ve sınıf öğretmenlerinin branş öğretmenlerine göre daha fazla örgütsel bağlılık yaşadığı sonucuna ulaşılmıştır. Araştrmacılar bu durumun nedenlerine ilişkin derinlemesine analiz içeren çalışmalar yapabilirler. Böylece eğitim paydaşlarına öğretmenlerin örgütsel bağlıııklarını artırmaya yönelik yapılacak çalışmalarda vizyon oluşur.

- Araştırmacıların ürettikleri birincil araştırmalarda daha sonra meta analizlerinin yapılacak gibi duyarlı davranarak gerekli istatistikleri raporlamaları gereklidir.

- Illgililer, Yükseköğretim Kurumu Tez Merkezi Veri Tabanında erişim izni olmayan tezlerin meta-analiz çalışmalarına engel teşkil etmemesi için çözüm üretmelidir. Ayrıca Türkiye'de tam olarak akademik makalelerin indekslendiği bir veri tabanı oluşturulmalıdır.

\section{Kaynakça}

Acar, T. (2015). Bilimsel Araştrma Yöntemlerinden Nitel ve Nicel Araştrma Retoriğine. Eğitimde ve Psikolojide Ölçme ve Değerlendirme Dergisi, 1(1), 10-16.

*Akgül, Z. (2014). Örgütsel bağllık ve tükenmişsik arasındaki ilişkinin matematik öğretmenlerinin algılarına göre incelenmesi. (Yüksek lisans tezi). Cumhuriyet Üniversitesi, Eğitim Bilimleri Enstitüsü, Sivas.

*Akyol, P., Atan. T., \& Gökmen, B. (2012). Beden eğitimi ve sınıf öğretmenlerinin örgütsel bağllıık düzeylerinin incelenmesi. Spor ve Performans Araştrrmaları Dergisi, 4(1), 38-45.

Allen, N. \& Meyer, J. (1990). The measurement and antecedents of affective, continuance, and normative commitment to the organization. The Journal Of Occupational Psychology, 63(1), 1-18.

*Aslan, i. (2017). Öğretmenlerg̉n pozitif psikolojik sermaye algıları ile örgütsel bağlılıları arasındaki ilişkinin incelenmesi. (Yüksek lisans tezi). Siirt Üniversitesi, Sosyal Bilimler Enstitüsü, Siirt.

Aven, F. F., Parker, B., \& Mcenvoy, G. M. (1993). Gender and attitudinal commitment to organizations: a meta analysis. Journal Of Applied Psychology, 26(1), 63-73.

Aydin, A., Sarier, Y., \& Uysal, S. (2011). The effect of gender on organizational commitment of teachers: a meta analytic analysis. Educational Sciences: Theory and Practice, 11(2), 628-632.

*Aydoğan, S. E. (2010). Resmi liselerde çalışan öğretmenlerin örgütsel bağlılık düzeyleri. (Yüksek lisans tezi). Beykent Üniversitesi, Sosyal Bilimler Enstitüsü, İstanbul.

*Başyiğit, F. (2009). Öğretmenlerin karar alma sürecine katlım düzeylerinin örgütsel bağllıı düzeyleri ile ilişkisi. (Yüksek lisans tezi). Gazi Üniversitesi, Sosyal Bilimler Enstitüsü, Ankara.

Billingsley, B. S., \& Cross, L. H. (1992). Predictors of commitment, job satisfaction, and intent to stay in teaching: A comparison of general and special educators. The Journal of Special Education, 25(4), 453-471.

Borenstein, M., Hedges, L. V., Higgins, J. P. T., \& Rothstein, H. R. (2009). Introduction to meta-analysis. West Sussex, UK: John Wiley \& Sons, Ltd.

Büyüköztürk, S., Kılıç Çakmak, E., Akgün, Ö. E., Karadeniz, S., \& Demirel, F. (2012). Bilimsel Arastirma Yöntemleri (18. Baskı). Ankara: Pegem Akademi Yayımclık.

Caught, K. \& Shadur. (2000). The measurement artifact in the organizational commitment questionnaire. Psychological Reports, 87(3), 777-788.

Chalmers, I., Hedges, L. V., \& Cooper, H. (2002). A brief history of research synthesis. Evaluation \& The Health Professions, 25(1), 12-37.

*Coşkun, E., (2012). Okul yöneticilerinin etkililiği ile öğretmenlerin örgütsel bağılı̆̆ı̆ arasındaki ilişki (İstanbul-Bağcılar örneği). (Yüksek lisans tezi). Yeditepe Üniversitesi, Sosyal Bilimler Enstitüsü, İstanbul. 
Culver, S. M., Wolfle, L. M., \& Cross, L. H. (1990). Testing a model of teacher satisfaction for blacks and whites. American Educational Research Journal, 27(2), 323-349.

Dinçer, S. (2014). Eğitim bilimlerinde uygulamalı meta-analiz. Pegem Atff İndeksi, 2014(1), 1-133.

Ebmeier, H. (2003). How supervision influences teacher efficacy and commitment: An investigation of a path model. Journal of Curriculum and Supervision, 18(2), 110-141.

Eisenberger, R., Karagonlar, G., Stinglhamber, F., Neves, P., Becker, T. E., Gonzalez-Morales, M. G., \& Steiger-Mueller, M. (2010). Leadermember exchange and affective organizational commitment: the contribution of supervisor's organizational embodiment. Journal Of Applied Psychology, 95(6), 1085.

Erkuş, A. (2009). Davranış bilimleri için bilimsel araştırma süreci. Ankara: Seçkin Yayıncılık.

Firestone, W. A., \& Pennell, J. R. (1993). Teacher commitment, working conditions, and differential incentive policies. Review of Educational Research, 63(4), 489-525.

Firestone, W. A., \& Rosenblum, S. (1988). Building commitment in urban high schools. Educational Evaluation and Policy Analysis, 10 (4), $285-299$.

Fresko, B., Kfir, D., \& Nasser, F. (1997). Predicting teacher commitment. Teaching and Teacher Education, 13(4), 429-438.

Gedik, A., \& Üstüner, M. (2017). Eğitim Örgütlerinde Örgütsel Bağlılık ve İş Doyumu ilişkisi: Bir Meta-Analiz Çalışması. e-Ulus/ararası Eğitim Araştirmaları Dergisi, 8(2), 41-57.

Glass, G. V. (2006). Meta-analysis: The quantitative synthesis of research findings. In J. L. Green, P. B. Elmore \& G. Camilli (Eds.), Handbook of Complementary Methods in Education Research. Mahwah: Lawrence Erlbaum Associates.

*Gören, T. (2012). Illköğretim kurumlarında görev yapan yönetici ve öğretmenlerin örgütsel bağılık düzeyleri (Aydın ili örneği). (Yüksek lisans tezi). Adanan Menderes Üniversitesi, Sosyal Bilimler Enstitüsü, Aydın.

Hedges L. \& Olkin I. (1985) Statistical methods for meta-analysis. San Diego, CA: Academic Press.

Hedges, L. V., \& Vevea, J. L. (1998). Fixed-and random-effects models in meta-analysis. Psychological Methods, 3(4), $486-504$.

Huedo-Medina, T. B., Sánchez-Meca, J., Marín-Martínez, F., \& Botella, J. (2006). Assessing heterogeneity in meta-analysis: Q statistic or ${ }^{2}$ index?. Psychological methods, 11(2), 193.

Hunter, J. E., \& Schmidt, F. L. (2004). Methods of meta-analysis: Correcting error and bias in research findings. California: Sage Publications.

*Karaköse, B. (2012). Rehberlik ve araştırma merkezlerinde çalışan personelin örgütsel bağlılık ve çalışma yaşamı kaliteleri arasındaki ilişkinin incelenmesi. (Yüksek lisans tezi). Erciyes Üniversitesi, Eğitim Bilimleri Enstitüsü, Aydın.

*Kaygısız, A. G. (2012). ilköğretim öğretmenlerinin örgütsel bağlıık düzeyleri ve karara katılma durumları arasındaki ilişki: Kütahya örneği. (Yüksek lisans tezi). Eskişehir Osmangazi Üniversitesi, Eğitim Bilimleri Enstitüsü, Eskişehir.

*Kılıçoğlu, G. (2010). Illköğretim okulu öğretmenlerinin örgütsel bağlılık algılarının bazı değişkenler açısından incelenmesi. (Yüksek lisans tezi). Ege üniversitesi, Sosyal Bilimler Enstitüsü, İzmir.

*Korkmaz, H. (2014). Ortaöğretim devlet okullarında görev yapan öğretmenlerin yabancılaşma düzeyleri ile örgütsel bağlılıları arasındaki ilişkinin incelenmesi.(Yüksek lisans tezi). Bahçeşehir Üniversitesi, Eğitim Bilimleri Enstitüsü, İstanbul.

*Korkmaz, O. (2014). Öğretmenlerin psikolojik sermaye algıları ile örgütsel bağlılık düzeyleri arasındaki ilişki (Kahramanmaraş Örneği). (Yüksek lisans tezi). Zirve Üniversitesi, Sosyal Bilimler Enstitüsü, Gaziantep.

*Kurşunoğlu, A., Baka, E. \& Tanrıöğen, A. (2010). Illköğretim okulu öğretmenlerinin örgütsel bağlılık düzeyleri. Pamukkale Üniversitesi Eğitim Fakültesi Dergisi, 28(28), 101-115.

Kushman, J. W. (1992). The organizational dynamics of teacher workplace commitment: A study of urban elementary and middle schools. Educational administration quarterly, 28(1), 5-42.

Lub, X., Nije Bijvank, M., Matthijs Bal, P., Blomme, R., \& Schalk, R. (2012). Different or a like? Exploring the psychological contract and commitment of different generations of hospitality workers. International Journal Of Contemporary Hospitality Management, 24(4), 553-573.

Mathieu, J. E., \& Zajac, D. M. (1990). A review and meta-analysis of the antecedents, correlates and consequences of organizational commitment. Psychological Bulletin, 108 (2), 171-194.

*Menep, İ. (2009). Illköğretim okullarında görev yapan öğretmenlerin örgütsel bağlıı̆g ilişkin algı düzeylerinin incelenmesi (Şırnak/idil örneği). (Yüksek lisans tezi). Abant İzzet Baysal Üniversitesi, Sosyal Bilimler Enstitüsü, Bolu.

Meyer, J. and Allen, N. (1991). 'A three component conceptualization of organizational commitment', Human Resource Management Review, 1(1), 61-89.

Mowday, R. T., Porter, L. W., \& Steers, R. (1982). Organizational linkage: the psychology of commitment, absenteeism and turnover. Organizational and Occupational Psychology, 10(3), 2008.

Mowday, R. T., Steers, R. M., \& Porter, L. W. (1979). The measurement of organizational commitment. Journal of vocational behavior, 14(2), 224-247.

Mullen, B., Muellerleile, P., \& Bryant, B. (2001). Cumulative meta-analysis: a consideration of indicators of sufficiency and stability. Personality and Social Psychology Bulletin, 27(11), 1450.

Niehoff, R. L. (1997). Job Satisfaction, Organizational Commitment, and Individual and Organizational Mission Values Congruence: Investigating the Relationships. (Doctoral dissertation). Gonzaga University. 
O’Reilly, C., \& Chatman, J. (1986). Organizational commitment and psychological attachment: the effect of compliance, indentification and internalization on prosocial behavior. Journal Of Applied Psychology, 71 (3), 492-499.

*Özkan, S. (2010). Illköğretim okulu öğretmenlerinin örgütsel bağlı̆̆ğı ve iş değerleri. (Yüksek lisans tezi). Mersin Üniversitesi, Sosyal Bilimler Üniversitesi, Mersin.

Petticrew, M. (2003). Why certain systematic reviews reach uncertain conclusions. British Medical Journal, 326(7392), $756-758$.

Petticrew, M., \& Roberts, H. (2006). Systematic reviews in the social sciences: A practical guide. Malden: Balckwell Publishing.

Randall, D. (1990). 'The consequences of organizational commitment: methodological investigation', Journal of Organizational Behavior, 11, 361-378.

Reames, E. H., \& Spencer, W. A. (1998). Teacher Efficacy and Commitment: Relationships to Middle School Culture. Paper presented at the annual meeting of the American Educational Research Association, San Diego, CA.

Reyes, P. (1990). Teachers and Their Workplace: Commitment, Performance, and Productivity. Newbury Park :Sage Publications.

Riehl, C., \& Sipple, J. W. (1996). Making the most of time and talent: Secondary school organizational climates, teaching task environments, and teacher commitment. American Educational Research Journal, 33(4), 873-901.

Riketta, M. (2002). Attitudinal organizational commitment and job performance: a meta-analysis. Journal of organizational behavior, 23(3), 257-266.

Rosenholtz, S. J. (1989). Workplace conditions that affect teacher quality and commitment: Implications for teacher induction programs. The Elementary School Journal, 89(4), 421-439.

Rosenthal, R. (1979). The file drawer problem and tolerance for null results. Psychological bulletin, 86(3), 638.

Rosenthal, R., \& DiMatteo, M. R. (2001). Meta-analysis: Recent developments in quantitative methods for literature reviews. Annual Review of Psychology, 52(1), 59-82.

*Selçuklu, A. E. (2013). Örgütsel bağlıı̆ın bir yordayıcısı olarak kurum kültürü ve psikolojik dayanıklılık: okulöncesi öğretmenler üzerine bir çalışma. (Yüksek lisans tezi). Erciyes Üniversitesi, Eğitim Bilimleri Enstitüsü, Kayseri.

*Serdaroğlu, R. (2013). Ortaöğretġm kurumlarındaki yöneticilerin yönetimde gücü kullanma stillerinin öğretmen algılarına göre örgütsel bağlılığa etkisi. (Yüksek lisans tezi). Trakya Üniversitesi, sosyal Bilimler Enstitüsü, Edirne.

Shann, M. H. (1998). Professional commitment and satisfaction among teachers in urban middle schools. The Journal of Educational Research, 92(2), 67-73.

Singh, K., \& Billingsley, B. S. (1998). Professional support and its effects on teachers' commitment. The journal of educational research, 91(4), 229-239.

Somech, A., \& Bogler, R. (2002). Antecedents and consequences of teacher organizational and professional commitment. Educational administration quarterly, 38(4), 555-577.

*Sönmez, M. (2016). Illkokul ve ortaokul öğretmenlerinin örgütsel bağlılıklarının çeşitli değişkenler açısından incelenmesi. (Yüksek lisans tezi). Bahçeşehir Üniversitesi, Eğitim Bilimleri Enstitüsü, İstanbul.

Tak, B., Acar Erdur, D., \& Kitapçı, N. (2011). Türkiye'de Örgütsel Bağlılık Yazını (2002-2010): Bir Meta-Analiz Çalışması.ļşletme Fakültesi Dergisi, 12(2), 335-353.

Thalheimer, W., \& Cook, S. (2002). How to calculate effect size from published research: a simplified spreadsheet. Erişim tarihi: 02.02.2018. http://www.work-learning.com/white_papers/ effect_sizes/effect_sizes_spreadsheet.xls adresinden erişilmiştir.

*Uştu, H. (2014). Sınıf öğretmenlerinin mesleki bağlılık, işten ayrılma niyeti ve sosyo demografik özelliklerinin örgütsel bağlılığı yordama düzeylerinin incelenmesi. (Yüksek lisans tezi). Çukurova Üniversitesi, Sosyal Bilimler Enstitüsü, Adana.

*Uysal, E. (2014). Lise öğretmenlerinin örgütsel güven algıları ile örgütsel bağlııkları arasındaki ilişki. (Yüksek lisans tezi). Gazi Üniversitesi, Sosyal Bilimler Enstitüsü, Ankara.

Ülbegi, İ. D., \& Yalçın, A. (2016). Örgütsel bağlılık ve iş doyumu ilişkisinin meta-analiz yöntemiyle incelenmesi. Türk Psikoloji Dergisi, 31(77), 80-98.

*Vurdu, U. (2017). Resmi okullarda görev yapan öğretmenlerin mesleki tükenmişlik durumları ile örgütsel bağlııları arasındaki ilişki. (Yüksek lisans tezi). Yeditepe Üniversitesi, Eğitim Bilimleri Enstitüsü, İstanbul.

*Yalçın, B. (2009). Eğitim örgütlerinde meyer ve allen üç boyutlu örgütsel bağlıık ölçeğinin geçerlik ve güvenirlik çalışması. (Yüksek lisans tezi). Gaziosmanpaşa Üniversitesi, Sosyal Bilimler Enstitüsü, Tokat.

Yılmaz, K., Altınkurt, Y., \& Yıldırım, H. (2015). Türkiye'deki öğretmenlerin örgütsel vatandaşlık davranışlarına cinsiyet, kıdem ve branş değişkenlerinin etkisi: Bir meta-analiz çalışması. Eğitim ve Bilim, 40(178), 285-304.

*Yörük, S., \& Sağban, Ş. (2012). Okul Müdürlerinin Kültürel Liderlik Rollerinin Öğretmenlerin Örgütsel Bağlılık Düzeyine Etkisi. Turkish Studies, 7(3), 2795-2813.

(* meta-analize dahil edilen birincil çalışmalar)

| Kastamonu Eğitim Dergisi, 27(3), 2019| 